\title{
ESTILOS ARQUITETÔNICOS EM ESPAÇOS CEMITERIAIS: CONTRIBUIÇÃO AOS ESTUDOS DE ARQUEOLOGIA FUNERÁRIA
}

\author{
Stela Glaucia Alves Bartheli \\ Ana Catarina Peregrino Torres Ramosii \\ Viviane M. Cavalcanti Castro ${ }^{\text {iii }}$
}

Resumo: Os cemitérios são espaços socialmente construídos, entendidos como espaços museais e possuem exemplares de arte e arquitetura que mostram as mudanças ocorridas nas sociedades. A arquitetura tumular, objeto e fonte de pesquisa da arqueologia funerária, leva em conta sua progressão conceitual e tipológica ao longo dos tempos. Este artigo examina estilos arquitetônicos em sete cemitérios em cidades do exterior e brasileiras. Foram analisados o Père Lachaise, em Paris, o Forest Lawn Memorial Park Hollywood Hills, em Los Angeles e o cemitério de La Recoleta, em Buenos Aires. No Rio de Janeiro, o cemitério São João Batista e no Recife três cemitérios: o do Senhor Bom Jesus da Redenção - cemitério de Santo Amaro, o cemitério dos Ingleses e o Bom Jesus do Arraial, o Cemitério de Casa Amarela. A abordagem está relacionada aos estudos cemiteriais com a interface da arqueologia funerária e arquitetura tumular. Foram analisados 40 jazigos, abarcando alguns estilos arquitetônicos. Este trabalho levantou as características destes jazigos, definindo os estilos empregados, mostrando a relação entre os estilos e o poder aquisitivo com o uso de materiais e técnicas correspondentes ao status socioeconômico dos proprietários dos jazigos.

Palavras-Chave: Estudos cemiteriais, Arquitetura funerária, Estilos arquitetônicos.

Abstract: Cemeteries are socially constructed spaces, understood as museum spaces and have examples of art and architecture that show the changes that occur in societies. The tumular architecture, object and research source of funeral archaeology, takes into account its conceptual and typological progression over time. This article examines architectural styles in seven cemeteries of three cities abroad and two Brazilian cities. Père Lachaise in Paris, Forest Lawn Memorial Park Hollywood Hills in Los Angeles and La Recoleta

Docente do Departamento de Arquitetura e Urbanismo da Faculdade de Ciências Humanas Esuda

E-mail: stela@esuda.edu.br

ii Docente do Departamento de Arqueologia da Universidade Federal de Pernambuco - UFPE.

E-mail: ana.tramos@ufpe.br

iii Docente do Departamento de Arqueologia da Universidade Federal de Pernambuco - UFPE.

E-mail: viviane.castro@ufpe.br cemetery in Buenos Aires were analyzed. In Rio de Janeiro, the cemetery São João Batista and in Recife three cemeteries: the Lord Bom Jesus of Redemption - cemetery of Santo Amaro, the cemetery of the English and the Bom Jesus of Arraial, the Cemetery of Casa Amarela. The approach is related to cemiterial studies with the interface of funeral archaeology and tumular architecture. Forty jazigos were analyzed, including some architectural styles. This work raised the characteristics of these deposits, defining the styles employed, showing the relationship between styles and purchasing power with the use of materials and techniques corresponding to the socioeconomic status of the owners of the deposits.

Key Words: Cemiteriais studies, Funeral architecture, Architectural styles. 


\section{Introdução}

Nas diversas vertentes abordadas nos estudos da arqueologia funerária a morfologia dos jazigos tem mostrado importância no tocante à diferenciação das características econômicosociais dos indivíduos ali sepultados. Em todas as expressões e formas da arquitetura estão refletidos os diversos momentos da sociedade, sendo um fruto do modo de viver dos diferentes grupos que formam essa sociedade. No entanto, na história da arquitetura sua materialização está presente, em grande parte, nos edifícios e espaços produzidos pelas classes dominantes, que as usam como marcos da passagem e de domínio sobre os outros. São edificações elaboradas com materiais resistentes ao tempo, com formas e maneiras de fazer que marcam uma época e que confirmam um controle social sobre as cidades e seus entornos. Como parte integrante desse cenário, os cemitérios não fogem à regra.

Quando, por exigências de ações higienistas, que pedem o distanciamento entre vivos e os corpos em decomposição e os sepultamentos extrapolam os recintos das igrejas, saindo do controle restrito das ordens religiosas, os cemitérios se tornam palco livre para essas demonstrações de riqueza e poder social. Os cemitérios particulares ou públicos que começam a se espalhar pelas cidades vão continuar a refletir essa condição, mostrando uma clara hierarquização social nos espaços (Castro, 2007). Nesse novo cenário, estão edificadas as moradas ou locais de descanso dos diversos segmentos da sociedade, mas é naquelas ligadas às categorias mais abastadas e de maior poder social que essas edificações adotam as mais perfeitas feições da arquitetura em termos de execução e elaboração artísticas.

Nos novos cemitérios construídos houve a reprodução do sistema de hierarquização social existente nos espaços urbanos, onde as construções de destaque remetem às classes mais abastadas, e como um local ideal para a europeização desses espaços, como ocorria nas cidades, criou uma teatralidade burguesa que deu um aspecto de imponência em parte dos ambientes nesses novos cenários. Nesses cemitérios localizados fora das igrejas, criados em meados do século XIX, os mortos eram advindos de todas as camadas sociais, e as classes não dominantes também buscaram se expressar utilizando-se de uma releitura dos chamados códigos civilizados, na construção dos túmulos. Neles são utilizados materiais diferentes, mas que se assemelham aos mais caros e formas semelhantes às usadas pelas elites, levando, desta forma, o discurso popular a se aproximar do elitista (Cymbalista, 2002). 
Os estilos arquitetônicos são, portanto, excelentes marcadores socioculturais, assim como importantes marcadores cronológicos. Esta compreensão é de grande valia nos estudos da arqueologia cemiterial, como um elemento caracterizador que auxilia na elaboração e uso dos espaços que os vivos ergueram e continuam erguendo para os seus mortos.

Visando uma contribuição na identificação das características arquitetônicas e artísticas dos jazigos, através do levantamento de informações visuais, com o uso de fotografias, buscou-se segregar estilos arquitetônicos presentes em alguns cemitérios, como auxílio às pesquisas no âmbito da arqueologia funerária. Assim, foram analisados estilos arquitetônicos empregados em 40 jazigos de sete cemitérios, três deles em cidades do exterior: o cemitério Père Lachaise, em Paris, público; o cemitério Forest Lawn Memorial Park Hollywood Hills, em Los Angeles, privado e o cemitério de La Recoleta em Buenos Aires, público, que são alguns dos cemitérios mais importantes do mundo, em termos de visitação, de monumentos e obras de arte, dos edifícios construídos e das pessoas que ali se encontram sepultadas. E ainda quatro cemitérios em duas cidades brasileiras, um dos cemitérios mais importantes do Brasil, o São João Batista, público, no Rio de Janeiro, que na época da sua construção era a capital do Império e três na cidade do Recife: no bairro de Santo Amaro, o Senhor Bom Jesus da Redenção, conhecido como cemitério de Santo Amaro, o mais antigo cemitério público da cidade e o cemitério dos Ingleses, conhecido como British cemetery, particular, que serviu à colônia inglesa que veio para Pernambuco por ocasião das instalações da Estrada de Ferro Recife-São Francisco (Melo, 2016) e no bairro de Casa Amarela, o Bom Jesus do Arraial, conhecido como cemitério de Casa Amarela, público. Dentre estes, o de Los Angeles é o único que foi construído no século XX. Todos os outros são do século XIX.

A escolha destes espaços se deu com base na existência de representações claras e tradicionais dos estilos arquitetônicos identificados em cada um deles. Como parte integrante de um projeto de pesquisa mais amplo, em desenvolvimento por professores e alunos do Departamento de Arqueologia da Universidade Federal de Pernambuco (UFPE), que aborda os espaços Cemiteriais existentes na cidade do Recife e regiões vizinhas, não serão tratadas aqui as variantes ou "adaptações" no tocante aos estilos arquitetônicos empregados nesses cemitérios. Uma abordagem mais ampla ocorrerá na continuidade da pesquisa. Planeja-se, em continuidade, realizar um amplo inventário fotográfico dos acervos tumulares dos cemitérios da Cidade do Recife e Região Metropolitana, como base e em auxílio às pesquisas em desenvolvimento 


\section{Estudos cemiteriais e arqueologia funerária}

Diferentes áreas das ciências vêm abordando os cemitérios históricos como objeto de estudos e na arqueologia essa prática vem crescendo intensamente nos últimos anos. O material funerário, visto como patrimonializável, levou à criação de políticas públicas preservacionistas dos cemitérios, o que acarretou a instituição do tombamento em parte deles, como ressalta Castro (2008). São "museus a céu aberto", repletos de símbolos artísticos-arquitetônicos que vão além da qualidade meramente utilitária e se tornam monumentos históricos de grande valor cultural (Borges, 2016). Assim, entendendo-se o potencial dos cemitérios como patrimônio, destaca-se a importância da pesquisa arqueológica para pensá-los como artefatos, decorrentes da vida social dos grupos humanos que os elaboraram e têm na concepção dos espaços, nos túmulos, lápides e ossuários a sua materialização. Como elementos elaborados e modificados pela ação humana estão, sem sombra de dúvidas, incluídos na categoria de artefatos (Orser Jr. 1992: 31). Por representarem a materialização das práticas funerárias, as mudanças no espaço, túmulos e lápides dos cemitérios históricos deixam evidentes os diversos momentos pelos quais passaram e passam até hoje, podendo ser estudados a partir dessas transformações.

No Brasil, os estudos cemiteriais vêm crescendo como campo de pesquisa há muitos anos. Em razão desse crescimento houve, em 2004, a criação da Associação Brasileira de Estudos Cemiteriais (Abec), que reúne profissionais de diferentes áreas do conhecimento, mostrando a amplitude do tema. Os estudos que esses diversos profissionais realizam sobre as práticas funerárias, através da materialidade evidenciada nos jazigos existentes nos cemitérios do Brasil e do mundo, de maneira geral, demonstram a sua importância como lugar de memória, cultura e arte e a interação com a vida da sociedade. Nos múltiplos elementos que formam os cemitérios históricos e em especial nos jazigos, são perceptíveis, através da arquitetura, das características estilísticas, das técnicas e materiais construtivos utilizados, as mudanças culturais e consequentes mudanças de comportamento nos cultos prestados aos mortos.

Entendendo-se a relação da cultura material dos cemitérios com a compreensão da vida e de suas manifestações sociais, nesse estudo foi realizada uma pesquisa dos aspectos arquitetônicos de mausoléus e túmulos destes cemitérios selecionados. A arqueologia permite uma interface com a arquitetura funerária, através da identificação de elementos caracterizadores arquitetônicos presentes nos jazigos. 
No Brasil, o primeiro trabalho de cunho arqueológico voltado ao estudo dos cemitérios históricos secularizados ou oitocentistas - quando os cemitérios saíram do domínio da igreja Católica e se tornaram extramuros - foi de autoria da arqueóloga Tania Andrade Lima (1994), que estudou o cemitério da Venerável Ordem Terceira dos Mínimos de São Francisco de Paula ou cemitério do Catumbi e o cemitério São João Batista, no Rio de Janeiro. A pesquisadora buscou compreender as mudanças políticas e sociais ocorridas na cidade do Rio de Janeiro, com a passagem do Império para a República. Pelo pioneirismo, este trabalho tornou-se referência para os estudos arqueológicos voltados para esta temática em todo o Brasil.

Numa rápida visão historiográfica sobre o tema, além da autora citada, em relação à arte funerária como reflexo social, muitos pesquisadores têm se dedicado ao tema. Valladares (1972), pesquisou, na década de 1960, a arquitetura tumular de diversas cidades brasileiras. No Rio Grande do Sul, Bellomo (1988, 2008), também considerado pioneiro na pesquisa histórica sobre arte funerária brasileira, defendeu a dissertação de mestrado intitulada " $A$ estatuária funerária em Porto Alegre (1900-1950)" e depois publicou Cemitérios do Rio Grande do Sul: arte, sociedade e ideologia. Maria Elizia Borges estuda a arte funerária desde a década de 1990 com dezenas de publicações, sendo uma referência na área (por exemplo: 1999, 2002, 2016). Ainda podem-se citar Motta (2009), que tratou dos aspetos sociais que envolvem a arte funerária; Reis (2011), que discutiu aspectos sociais no processo de mudança ocorrido na implantação do cemitério de Salvador e o Brasil Oitocentista como um todo, e Castro (2007), que trouxe a discussão para terras recifenses.

Nos anais das reuniões da ABEC fica clara a importância do tema pelos inúmeros trabalhos apresentados, como por exemplo os de Elisiana Trilha Castro $(2008,2010)$ que trata da arte funerária nos cemitérios, além de se dedicar à questão dos inventários e preservação do patrimônio funerário brasileiro. Ainda como pesquisadores dos estudos cemiteriais e membros da ABEC pode-se mencionar Cláudia Rodrigues (1997, 2005), Fabiana Comerlato (2012), Comerlato et al. (2013), Marcelina Almeida (2007, 2013), dentre outros.

No Departamento de Arqueologia da UFPE, a pesquisa e os estudos cemiteriais vêm se ampliando e consolidando nos últimos 12 anos. A produção citada a seguir está vinculada a ele, como por exemplo Costa e Castro (2015), cujo objetivo foi realizar o diagnóstico do atual estado de conservação dos primeiros túmulos (de 1851 a 1900) estabelecidos no Cemitério de Santo Amaro, no Recife. Os resultados demonstram degradação natural e antrópica, 
ocasionada pelo tempo, pela falta de atitude política e pelo não reconhecimento por parte da sociedade contemporânea.

Por sua vez, Santos (2016) realizou uma análise preliminar em uma amostra da arte tumular dos túmulos históricos do Cemitério de Santo Amaro, fazendo um comparativo entre túmulos da segunda metade do século XIX e túmulos da primeira metade do século XX, levando em consideração os signos presentes, a matéria-prima, tipologias, tipo de arte e tipo de jazigo. Os resultados indicaram que ocorreram algumas mudanças, mas que não há necessariamente, uma descontinuidade de elementos decorativos dos túmulos.

O estudo realizado por Machado e Castro (2017) objetivou compreender quais grupos socioeconômicos estão representados materialmente nos jazigos do cemitério de Santo Amaro entre 1851-1900. Os resultados indicam haver distinção social no interior do cemitério e essa é percebida nos jazigos, nos signos utilizados para a decoração tumular e na localização dos sepultamentos.

Através das representações femininas existentes na arte tumular dos jazigos históricos, inseridos a partir da segunda metade do século XIX e primeira metade do século XX, o trabalho de Paz (2018) objetiva identificar e analisar mudanças e continuidades nos elementos materiais dos jazigos e discutir numa perspectiva de gênero os tipos de representações femininas existente na arte tumular do Cemitério de Santo Amaro. Em Cruz (2019) o estudo objetivou observar as mudanças ocorridas na arte funerária do Cemitério dos Ingleses, entre o século XIX e a primeira metade do século XX. Foi identificado que na passagem dos séculos houve o desaparecimento de alguns tipos de elementos característicos da arte tumular como a matéria - prima, tipo de arte e signos, mas houve a continuidade do tipo de jazigo, e, o aparecimento de novos estilos funerários, como esculturas isoladas e o aparecimento de cenas.

O estudo de Silva (2019) tem como objeto de estudo o Cemitério de Santo Amaro do Recife, e objetiva compreender o uso da materialidade para representar os indivíduos, em dois momentos históricos, da criação até o fim do Império (1851-1889) e na Primeira República (1889-1930). Os resultados indicam que os elementos que compõe a materialidade dos túmulos representam a figura do patriarca, conotando poder, prestígio social enquanto a mulher tem sua memória atrelada à figura masculina, com pouca visibilidade. 
Freitas, Ramos e Kaufman (2019) realizaram estudo em um cemitério localizado no Bairro do Recife, núcleo inicial de formação da cidade, associado ao período de ocupação holandesa, no século XVII. Sem informações historiográficas, as pesquisas arqueológicas trouxeram à tona importantes informações históricas sobre esse período. $\mathrm{O}$ trabalho trata dos 65 sepultamentos pesquisados, de um universo de mais de 100 . Foram trabalhados dados históricos e aspectos biológicos dos indivíduos sepultados, na busca de marcadores de identidade que permitissem uma associação cultural da materialidade estudada com o período proposto.

Outros trabalhos de pesquisa, ainda em andamento tratam do cemitério Público Municipal da Várzea, fundado em 1867, localizado nas vizinhanças do campus-Recife da UFPE e do cemitério público urbano de São Sebastião, na cidade de Vitória de Santo Antão, em Pernambuco, construído em 1875, objeto de uma tese de doutorado em finalização.

Neste trabalho a atenção está voltada para os estilos arquitetônicos presentes nos jazigos e que envolvem as representações da sociedade no interior dos cemitérios a partir da segunda metade do século XIX. Como a arquitetura é um reflexo da sociedade que a constrói, os cemitérios refletem através dela, nos elementos que compõem os jazigos, a forma como os mortos são lembrados e homenageados. Os estilos arquitetônicos são datados, pertencem a um determinado tempo e vão sendo substituídos por outros mais modernos, seguem modas. Isto tem correlação com as mudanças ocorridas na sociedade, em termos sociais, políticos e econômicos. Em termos de arquitetura, o estudo dos cemitérios permite acompanhar através das construções, os estilos e as substituições ocorridas ao longo do tempo, assim como as técnicas construtivas, os materiais utilizados, os revestimentos. Como nas cidades, nos cemitérios a presença dos tempos está expressa na materialidade dos edifícios (Fuchs, 2019).

\section{Os cemitérios extramuros}

Alguns fatores foram responsáveis pelo surgimento dos primeiros cemitérios extramuros, como a ocorrência de doenças infectocontagiosas, com a disseminação de gases e dos miasmas decorrentes do processo de decomposição dos corpos, o que tornou inviável a prática dos sepultamentos dentro das igrejas (conhecidas como ad sanctus, em latim, com os santos). Enterros perto de Deus eram uma garantia de vida plena depois da morte (Reis, 1997).

Durante o governo de Napoleão Bonaparte, na França, chamado de "Primeiro Império", surgiram políticas higienistas e o Decreto de 12 de junho de 1804 trouxe recomendações que 
são seguidas ainda hoje, como a proibição dos enterramentos dentro das igrejas e nos pátios em frente e ao redor destas, como era normal para as pessoas de maior poder aquisitivo. Foi também estabelecido o distanciamento das sepulturas entre 35,00 a 40,00 m dos limites das áreas urbanas além do distanciamento entre as sepulturas (Favaretto, 2017). Foram concedidas às famílias que faziam doações aos hospitais e para os desvalidos as permissões para construírem jazigos perpétuos. Inicialmente, as áreas escolhidas eram afastadas das cidades, mas com a sua expansão, os cemitérios acabaram sendo absorvidos na área urbana.

No Brasil no período colonial e durante o Império, os sepultamentos aconteciam no piso das naves das igrejas ou nos altares e ossuários das capelas dos sítios e engenhos. Os escravos e os desvalidos eram enterrados nas praias, nos terrenos baldios, nos campos (Medeiros, 2012; Rodrigues, 2014) ou ainda nos cemitérios pertencentes à Santa Casa de Misericórdia. Para a população não católica, no Rio de Janeiro e em Salvador, assim como no Recife, havia também um cemitério dos Ingleses, para o enterro de pessoas protestantes, por causa da proibição de se enterrarem nas igrejas católicas os não católicos, como os protestantes, além dos suicidas, os escravos, os que morriam sem batismo, os maçons, os condenados, e os usurários, os que emprestavam dinheiro a juros altos, prática condenada pelo Catolicismo (Castro, 2013).

Com as políticas higienistas foram erguidos cemitérios públicos em várias cidades do país. Eram extramuros, fora dos limites das cidades, nos arrabaldes, assim como em outras partes do mundo, seguindo os princípios do higienismo. No final do século XIX, com a passagem do regime monárquico para a República (1889), ocorreu o que se conhece por secularização, o processo de desvinculação da Igreja Católica dos ritos de sepultamento nos cemitérios. Na época do Império, o Catolicismo era a religião oficial do Brasil. Com a República e a nova Constituição de 1891, vieram a permissão para que outras práticas religiosas pudessem se expressar livremente e a transmissão da administração dos cemitérios para os municípios, o que se configurou como uma perda de poder para a Igreja Católica (Gomes, 2013).

\section{Estilos arquitetônicos}

Estilo é algo que pode ser reconhecido por um certo número de características que são comuns às obras de arte de um mesmo período cronológico, incluindo-se as obras de arquitetura. À luz da arqueologia, pode ser reconhecido pelos elementos presentes na cultura material, através de técnicas de construção e dos materiais empregados e das formas e 
maneiras de fazer que se configuram como um padrão em determinada época da história de uma sociedade (Koch, 2001).

Por conta do recorte cronológico a partir do século XIX, quando seis dos sete cemitérios aqui selecionados foram construídos, o que se esperava encontrar em termos de arquitetura funerária era inicialmente o estilo neoclássico, que estava vigente na época em que os cemitérios extramuros foram criados. No mundo o neoclássico se encontra datado entre 1760 e 1830. No Brasil o estilo foi difundido a partir da chegada da Missão Francesa ao Rio de Janeiro, em 1816, mas com pequenas ocorrências em algumas cidades brasileiras antes disto, como Belém do Pará, com as obras do arquiteto italiano Antônio Landi e o Recife (Souza, 2000). O neogótico veio na sequência, no início do século XIX, principalmente com as obras de Viollet-le-Duc, arquiteto francês, com o restauro de edifícios da época gótica, do final da Idade Média, como a basílica de Saint Denis, a cidade medieval de Carcassone, a catedral de NôtreDame, em Paris, entre outras (Koch, 1982). No Brasil, este estilo foi muito empregado em obras religiosas. O Ecletismo e dentro deste a chamada "Arquitetura do ferro", trouxe o revivalismo de estilos do passado e a justaposição deles numa mesma obra. O Art Nouveau faz parte do Ecletismo, mas não foi encontrado nesta seleção de jazigos nenhum exemplar. Em relação à Arquitetura do ferro, que tem como característica o uso do ferro aparente em estrutura, vedação ou ornamentos, não existem jazigos, mas sim componentes em ferro para as obras, como grades, guarda-corpos, bandeiras para janelas e portas, portões etc. Exemplos disto são os portões em ferro fundido do cemitério de Santo Amaro e do cemitério dos Ingleses. Outra característica é o fato de o edifício poder ser montado e desmontado, o que não é o caso dos jazigos. $\mathrm{O}$ art déco do início do século XX traz o geometrismo, os ornamentos estilizados, em alusão à fauna e a flora, platibandas escalonadas, planos escalonados e superpostos, frisos, linhas aerodinâmicas e finalmente o modernismo, com ausência de ornamentos, o uso do concreto armado e linhas retas. Cada um deles tem elementos, técnicas e materiais característicos, produtos da época em que foram construídos. O quadro a seguir lista alguns dos principais elementos da cultura material presentes nestes estilos, que puderam ser identificados nos jazigos apresentados (Quadro 1). 
Quadro 1: Principais características dos estilos arquitetônicos.

\begin{tabular}{|c|c|c|}
\hline ESTILO & ELEMENTOS DA CULTURA MATERIAL & CRONOLOGIA \\
\hline Neoclássico & $\begin{array}{l}\text { Elementos da arquitetura greco-romana, do } \\
\text { Renascimento e Maneirismo: arcos plenos, } \\
\text { frontões triangulares, entablamentos, ordens } \\
\text { arquitetônicas (Dórica, Jônica, Coríntia, Toscana } \\
\text { e Compósita), pódio, cúpulas. Sistema } \\
\text { construtivo: alvenaria de pedra. Revestimento: } \\
\text { mármore, granito. Podia ser usada a caiação e } \\
\text { ainda azulejos (Lemos, 1987). }\end{array}$ & Entre 1760 até 1830. \\
\hline Neogótico & $\begin{array}{l}\text { Elementos que fazem alusão à Arquitetura do } \\
\text { final da Idade Média, releitura do estilo Gótico: } \\
\text { verticalidade, arcos ogivais, coruchéus, torres } \\
\text { pontiagudas e esguias, ameias, vitrais, óculos. } \\
\text { Sistema construtivo: alvenaria de pedra. Uso do } \\
\text { ferro na estrutura (Del Brenna, 1987). }\end{array}$ & Século XIX. \\
\hline Ecletismo & $\begin{array}{l}\text { Mistura de estilos. Revivalismo de estilos do } \\
\text { passado: "Neos". Jarros, ânforas, bustos e } \\
\text { estátuas nas platibandas. Ornamentos de } \\
\text { estuque. Edifícios exóticos, pitorescos. Sistema } \\
\text { construtivo: alvenaria de pedra ou de tijolo. Uso } \\
\text { do ferro e do vidro. Revestimentos cerâmicos } \\
\text { (Gomes, 1987). }\end{array}$ & $\begin{array}{l}\text { Final do século XIX até } \\
\text { início do século XX. }\end{array}$ \\
\hline Art Déco & $\begin{array}{l}\text { Simetria, figuras geométricas, predomínio das } \\
\text { linhas retas, escalonamentos, planos } \\
\text { superpostos, curvas, frisos dando ideia de } \\
\text { movimento, natureza estilizada (flores, animais). } \\
\text { Sistema construtivo: uso do concreto armado. } \\
\text { Revestimento: mármore, granito, pó de pedra } \\
\text { (fragmentos de mica adicionados ao reboco) } \\
\text { (Barthel, 2015). }\end{array}$ & $\begin{array}{l}\text { Início do século XX. } \\
\text { Entre as duas grandes } \\
\text { guerras mundiais. No } \\
\text { Brasil é tardio, indo até } \\
\text { finais dos anos } 50 \text { do } \\
\text { século XX. }\end{array}$ \\
\hline Modernista & $\begin{array}{l}\text { Uso do concreto armado, ausência de } \\
\text { ornamentos, amplas aberturas. }\end{array}$ & $\begin{array}{l}\text { Primeira metade do } \\
\text { século } X X \text {. }\end{array}$ \\
\hline
\end{tabular}

\section{Jazigo: o edifício funerário}

O edifício é o produto mais característico da arquitetura (Graeff, 1979). Os elementos que compõem um edifício qualquer organizam o espaço e as práticas humanas. Através dele, a vida se manifesta assim como a morte, a forma como as pessoas passam para a eternidade e como os mortos são lembrados e cultuados através de rituais. É ao mesmo tempo manifestação 
artística e reflexo da sociedade onde ele se insere. Delimita-se o espaço para uma determinada finalidade, no caso, dar destino aos restos mortais dos entes queridos.

Os edifícios que são mais estudados em história da arquitetura e história da arte são as moradias (Goitia, 1995): os palácios, como moradia dos reis, príncipes, faraós; os templos, como moradia dos deuses; a casa, como moradia do homem comum e os túmulos, como moradia dos mortos, a última moradia, que assinala a passagem das pessoas pela Terra, porque cemitérios são lugares de memória. Assim os mortos continuavam a fazer parte da vida da sociedade. Há diversos tipos de edifícios funerários, dos mais simples aos mais requintados, cujos estilos podem ser percebidos e outros que não têm estilo definido.

Os jazigos são as estruturas onde estão sepultados os cadáveres e podem ser configurados estruturalmente como túmulo, ossuário e mausoléu (Lima, 1994: 96). De maneira geral, os jazigos que empregam estilos arquitetônicos são os mausoléus (divididos em mausoléuscapela e mausoléus-monumento) e túmulos, destinados às pessoas de maior poder aquisitivo, que podem dispor dos serviços de um arquiteto ou de um mestre de obras e de artistas, como escultores. Essa relação da elite com a opulência e maior cuidado com os jazigos presentes nos cemitérios pelas classes sociais mais abastadas é vista em muitos trabalhos já realizados no Brasil, como exemplo o de Machado e Castro (2017). Nele os autores buscaram entender que grupos socioeconômicos estavam representados nos jazigos do objeto da pesquisa, o cemitério de Santo Amaro, no Recife, na segunda metade do século XIX. A pesquisa encontrou arcabouço ideológico nas ideias de Pearson (1982), quando este descreveu as experiências advindas da análise do cemitério de Cambridge, na Inglaterra e discutiu os princípios que interferem e que atuam como elemento de ligação entre a cultura material à prática funerária bem como as relações sociais. Como o trabalho citado, a pesquisa desenvolvida buscou o elemento de ligação daquela sociedade oitocentista do Recife com as concepções da morte, procurando entender quais relações eram visíveis e como o elemento humano se representava, através dos signos, para vencer a morte e perpetuar seu nome ou o de sua família e mais ainda, a sua própria memória. Através da compreensão da arte tumular e da localização dos jazigos, os autores puderam afirmar que a elite recifense utilizou características ligada às práticas funerárias para perpetuar suas lembranças. Nos estilos arquitetônicos dos túmulos e mausoléus e nos elementos destes estavam as marcas dessa elite. 


\section{Estilos arquitetônicos presentes e cemitérios}

Há cemitérios que se destacaram em várias cidades do mundo, quer pela importância dos edifícios e obras de arte, quer pelas pessoas que ali se encontram sepultadas e se transformaram em destinos turísticos. Alguns são parques, outros são monumentos nacionais.

O cemitério Père Lachaise, em Paris, é um dos maiores do mundo, sendo também o mais famoso e o mais antigo dos quatro maiores cemitérios da cidade. O nome é uma homenagem a um padre, François D'Aix de La Chaise, confessor do Rei Luís XIV, pois as terras onde foi erguido haviam pertencido à Ordem Jesuíta, que foi expulsa do país antes do cemitério ser construído, no governo de Napoleão Bonaparte. O projeto feito em 1803 é do arquiteto Alexandre Brongniart e foi inaugurado no ano seguinte. Foram realizadas cinco ampliações, a última delas em 1850. Ficava distante do centro, numa área pobre, não sendo bem recebido, a princípio, pela população, além do fato de ser público, pois permitia que pessoas de qualquer classe fossem enterradas ali, algo que não era visto com bons olhos pelos mais abastados. Com a expansão da cidade, hoje o local onde situa-se o cemitério Père Lachaise, faz parte da cidade de Paris (Dansel, 1976).

O cemitério abriga os jazigos de personalidades importantes, não só para a história do país, como para a história mundial, como intelectuais, chefes de estado, músicos, artistas. Estão enterrados ali várias pessoas que estão fora dos seus lugares de nascimento, como o escritor inglês Oscar Wilde e o músico norte-americano Jim Morrison. O túmulo de Allan Kardec (Hippolyte Léon Rivail), criador da doutrina do Espiritismo, é eclético, neocéltico, se assemelha a um dólmen, monumento megalítico pré-histórico, que servia de tumba e altar de sacrifícios e é atribuído ao povo Celta, cuja tribo dos Francos deu origem ao país, a França. O edifício é formado por pedras de granito. É um dos lugares mais visitados do Père Lachaise (Figura 1).

O Barão Georges-Èugene Haussmann, responsável pela reforma urbana de Paris em meados do século XIX, está enterrado em um mausoléu-capela da família, ao lado de outro edifício no mesmo estilo neoclássico (Figura 2). O de Haussmann apresenta elementos da arquitetura greco-romana, mas também renascentista, maneirista, como um frontão triangular, um entablamento e arco pleno, alusão à ordem arquitetônica coríntia, com o pilar (e não coluna) com capitel com folhas de acanto e frisos canelados. O mausoléu-capela da família Boittelle, ao lado, apresenta frontão triangular com arco pleno inserido nele, maneirista, com a ordem arquitetônica toscana estilizada, com base e capitel. O maneirismo foi um movimento dentro 
do período da Renascença, de turbulência e guerra, onde os cânones da arquitetura grecoromana foram submetidos a experimentações, de uma maneira como nunca haviam sido empregados na Antiguidade. Os elementos são reconhecíveis, mas causam um certo estranhamento (Gombrich, 1999).

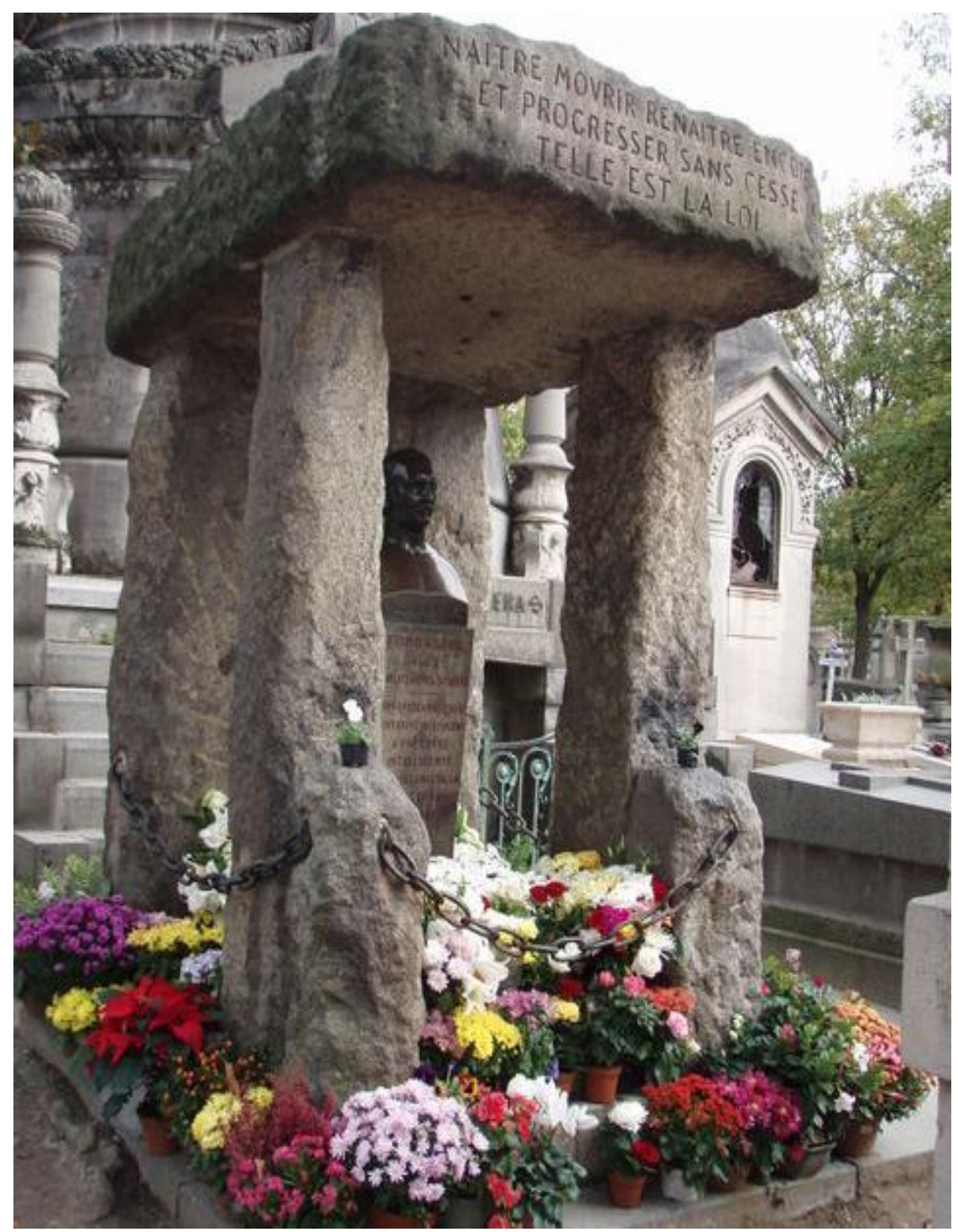

Figura 1: Cemitério Père Lachaise- Túmulo eclético neocéltico. Allan Kardec. Fonte: http://geak2002.blogspot.com/2011. 


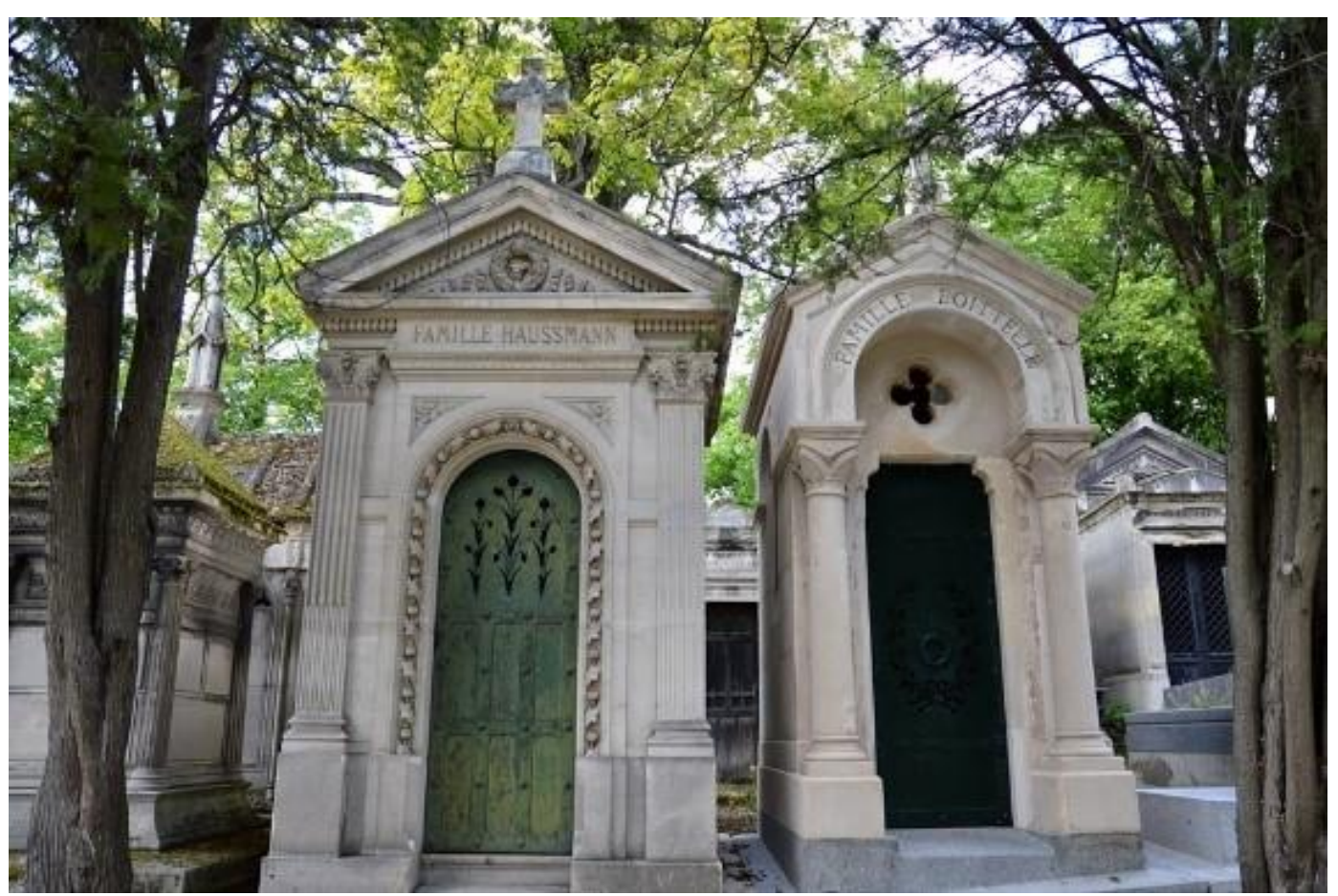

Figura 2: Cemitério Père Lachaise - Mausoléus-capela neoclássicos. Famílias Haussmann e Boittelle. Fonte: www.viajantesemfim.com.br

O exemplo a seguir é do tipo mausoléu-capela, neogótico (Figura 3), onde se notam a verticalidade, os arcos ogivais, os coruchéus, a inclinação do telhado e a presença de um óculo com arco trilobado, usado por vários estilos da Idade Média, com influência da arquitetura do Islã.

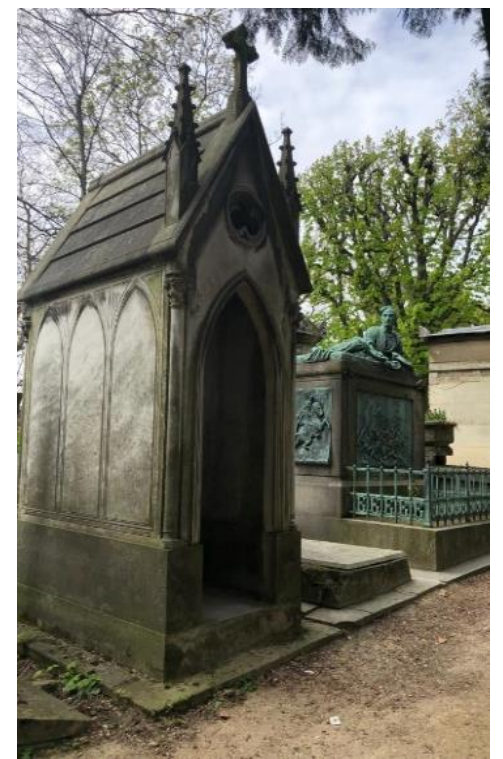

Figura 3: Cemitério Père Lachaise. Mausoléu-capela neogótico. Fonte: Leonardo Barthel, 2019. 
Os três exemplos a seguir (Figura 4) mostram o primeiro da esquerda para a direita neoclássico, com um frontão em arco abatido onde aparecem relevos e frisos, entablamento com frisos, ordem arquitetônica toscana, com base e caneluras e pódio. O segundo e o terceiro são ecléticos, bastante semelhantes, apenas de cores diferentes e misturam arcos plenos com arremates em arcos ogivais, inclinação dos telhados e verticalidade, apresentam relevos e há colunas da ordem coríntia, configurando-se como justaposição de estilos, com elementos da arquitetura clássica, greco-romana e do gótico.

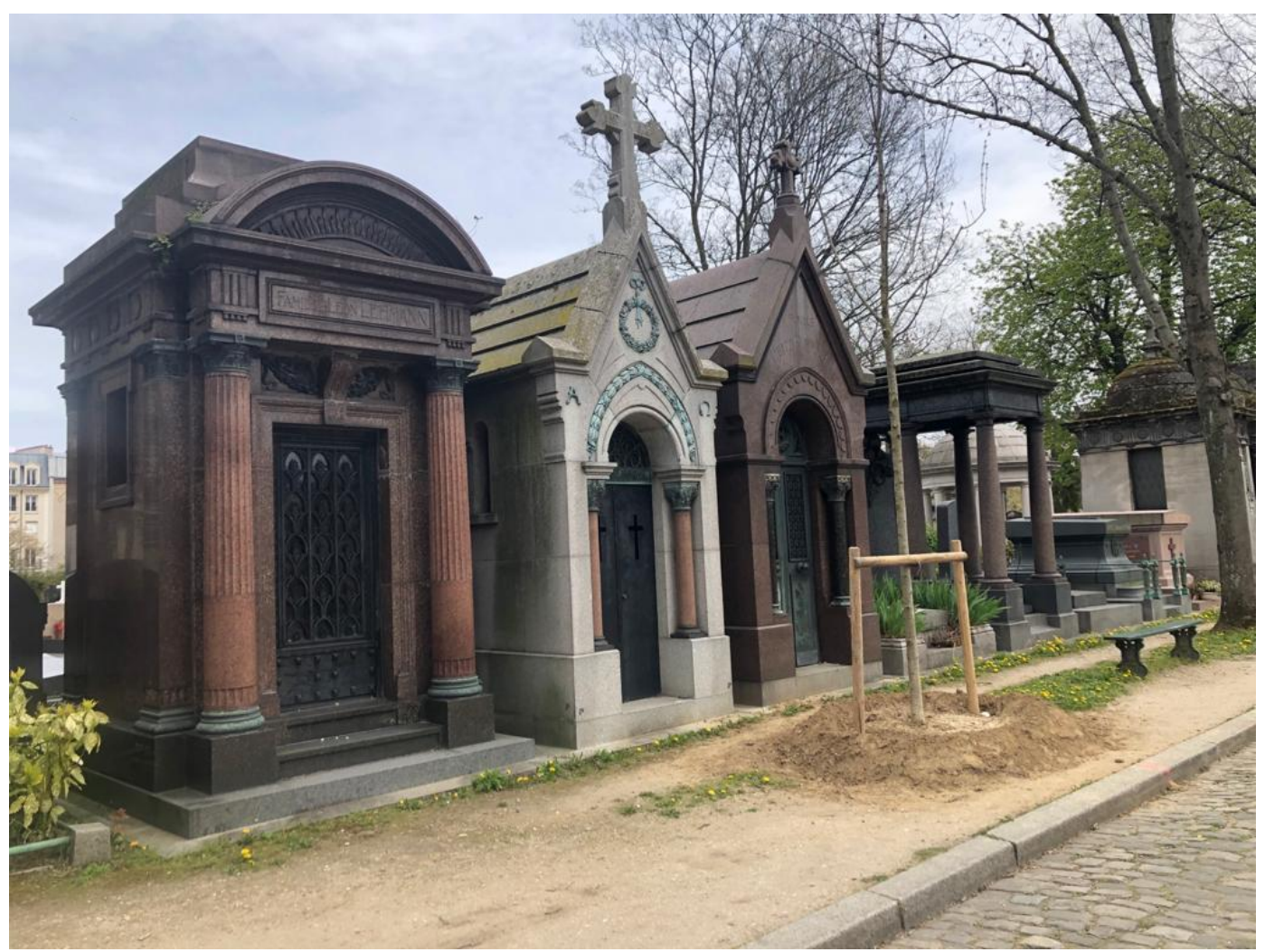

Figura 4: Cemitério Père Lachaise - Mausoléus-capela neoclássico e ecléticos. Fonte: Leonardo Barthel, 2019.

O cemitério Forest Lawn Memorial Park Hollywood Hills, em Los Angeles, é um dos maiores e mais luxuosos cemitérios do mundo e faz parte de uma rede de cemitérios-parque (Memorial parks), onze ao todo, com o nome de Forest Lawn e o nome das localidades onde ficam, na Califórnia, nos Estados Unidos. Faz parte do Griffit Park, onde fica o planetário e é um local onde se realizam grandes eventos e onde está também o letreiro com o nome de Hollywood, um dos marcos de Los Angeles. É um cemitério privado, onde estão enterrados muitos atores de cinema e teatro e artistas da música, além de personalidades políticas e grandes empresários. 
Foi construído em 1917 pelo empreendedor Hubert L. Eaton, inspirado no cemitério italiano de Campo Santo, na cidade de Gênova. Entra-se por um edifício eclético neorromânico, do tipo mausoléu-monumento, que é também a administração, assentado sobre arcos, que permite a passagem dos veículos (Figura 5).

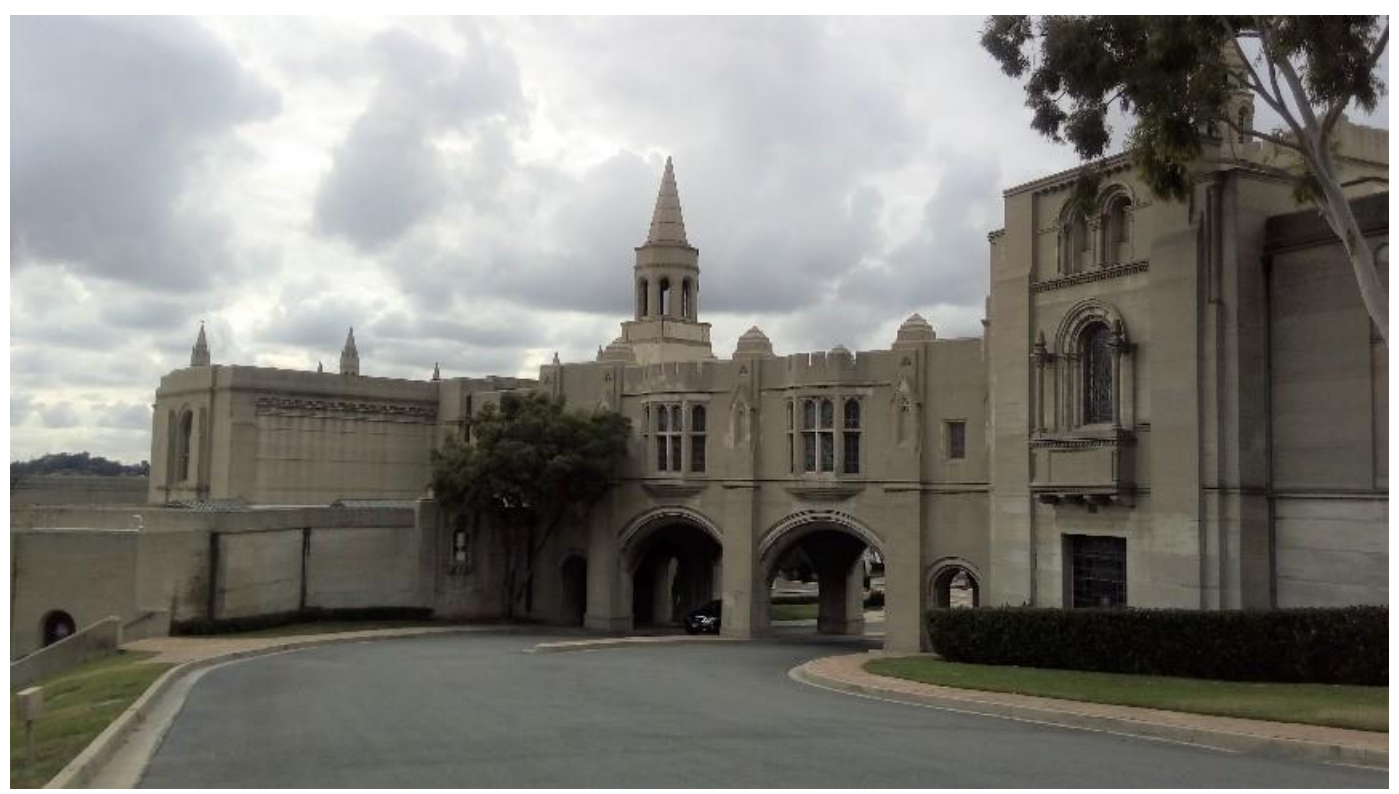

Figura 5: Cemitério Forest Lawn Memorial Park - Mausoléu-monumento eclético neorromânico. Fonte: Stela Barthel, 2017.

A maior parte dos edifícios apresenta o estilo eclético neorromânico, como no edifício onde se encontra o Credo do Construtor (The Buider's Creed, Figura 6) e no Mausoleum (Figura 7). As referências a estes estilos da Idade Média, como o românico e o gótico, encontram-se presentes nas torres, nas ameias, nos vitrais e óculos, nos arcos ogivais dos interiores, na verticalidade, nas torres esguias. Os jazigos encontram-se dentro deste mausoléu e do Grande Mausoléu, onde está a catedral, vários santuários e um columbário, onde se conservam as cinzas de pessoas que foram cremadas. Há jazigos espalhados pelos jardins, assim como inúmeras esculturas e obras de arte. 


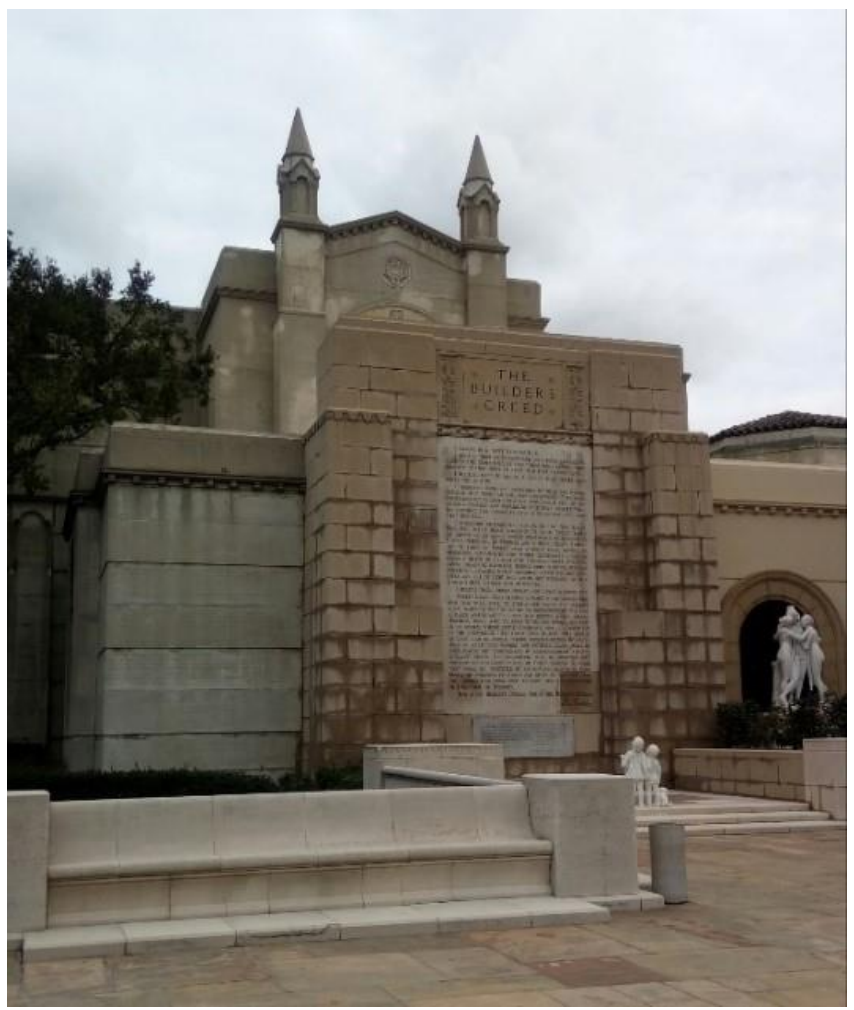

Figura 6: Cemitério Forest Lawn Memorial Park Mausoléu-monumento eclético neorromânico. The Builder's Creed. Fonte: Stela Barthel, 2017.

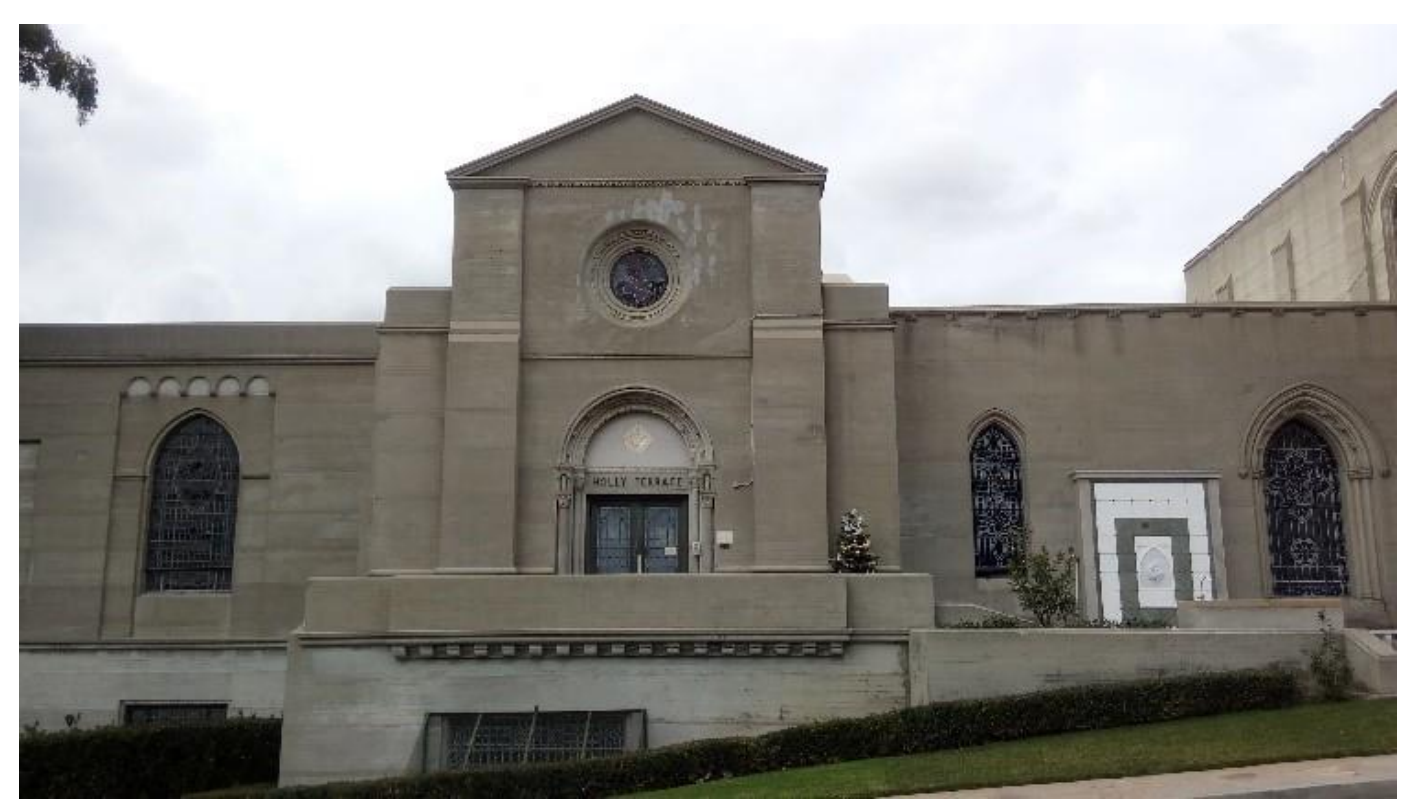

Figura 7: Cemitério Forest Lawn Memorial Park - Mausoléu-monumento eclético neorromânico. Fonte: Stela Barthel, 2017. 
O Great Mausoleum (Figuras 8 e 9) mistura elementos do neorromânico e do neogótico e abriga esculturas que são réplicas das obras de Michelangelo (Moisés, Madonas, Pietà) e um vitral baseado na obra de Leonardo da Vinci (A última ceia) feito por Rosa Moretti e há um grande vitral, conhecido como a Janela da Memória (The Memory Window, Figura 10).

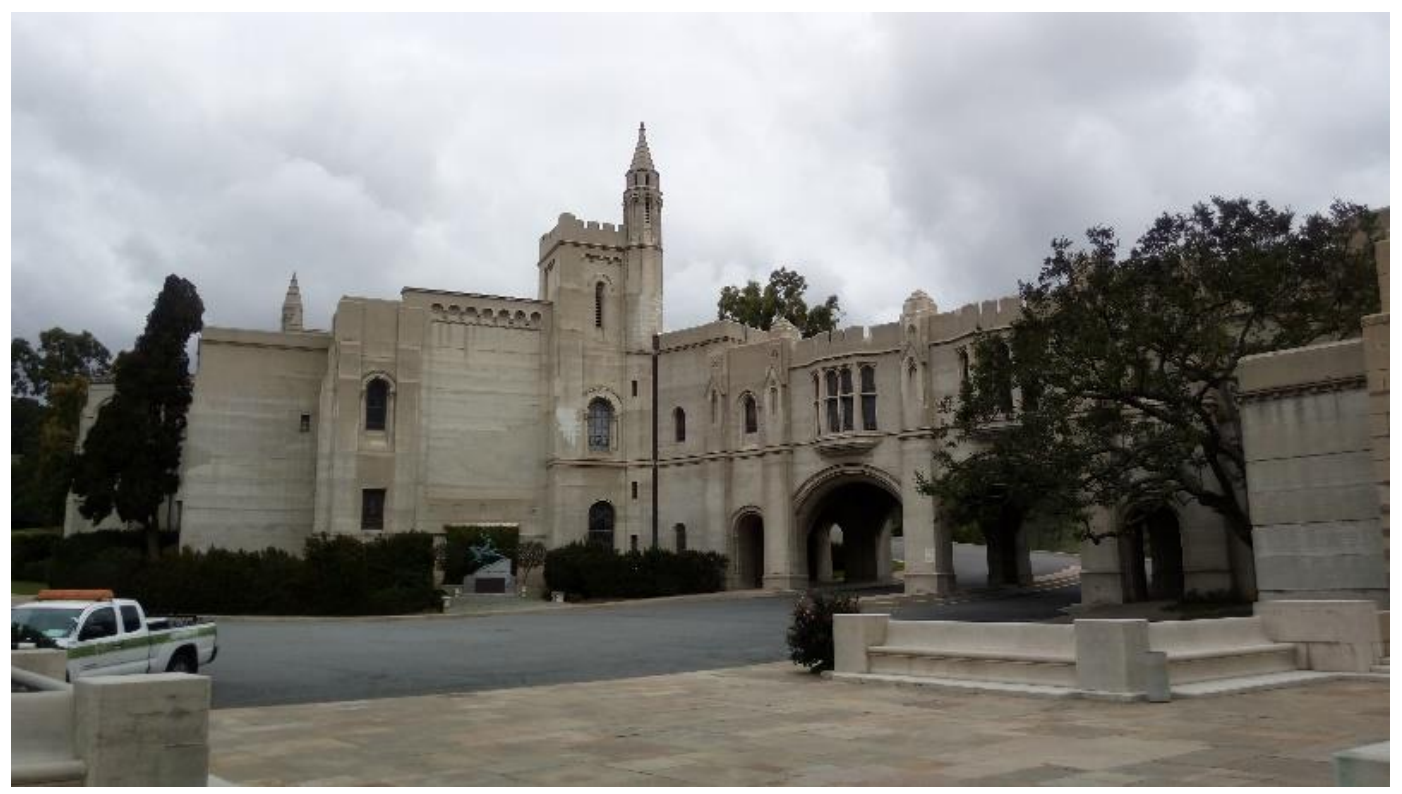

Figura 8: Cemitério Forest Lawn Memorial Park - The Great Mausoleum. Mausoléu-monumento eclético. Fonte: Stela Barthel, 2017.

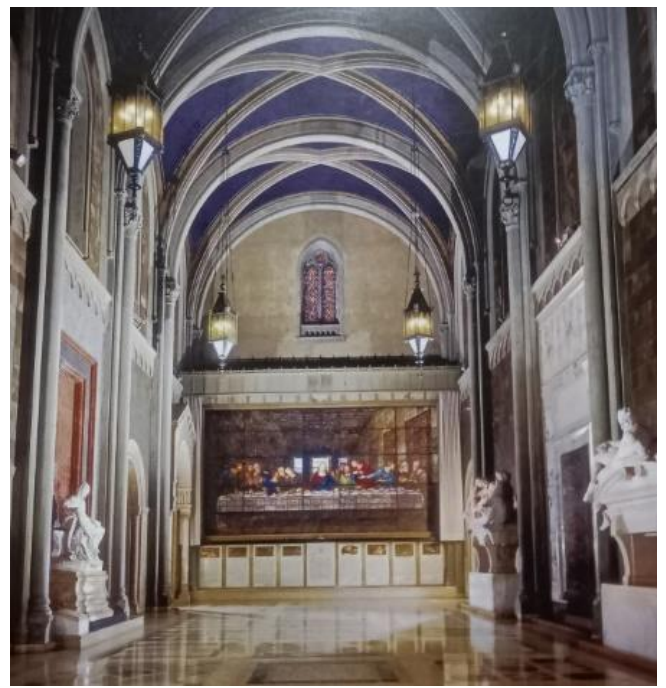

Figura 9: Cemitério Forest Lawn Memorial Park Interior do The Great Mausoleum. Fonte: The Great Mausoleum Tour Guide.

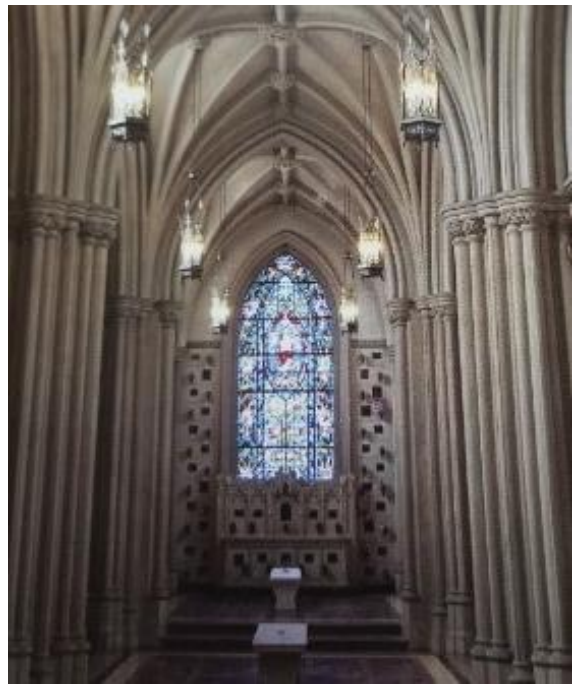

Figura 10: Cemitério Forest Lawn Memorial Park. Interior do The Great Mausoleum. Fonte: The Great Mausoleum Guide Tour. 
Alguns jazigos estão nos jardins em frente aos edifícios e formam pequenos recintos, com esculturas e bancos. O tumulo com escultura e letreiro tem elementos art déco, como o escalonamento (Figura 11).

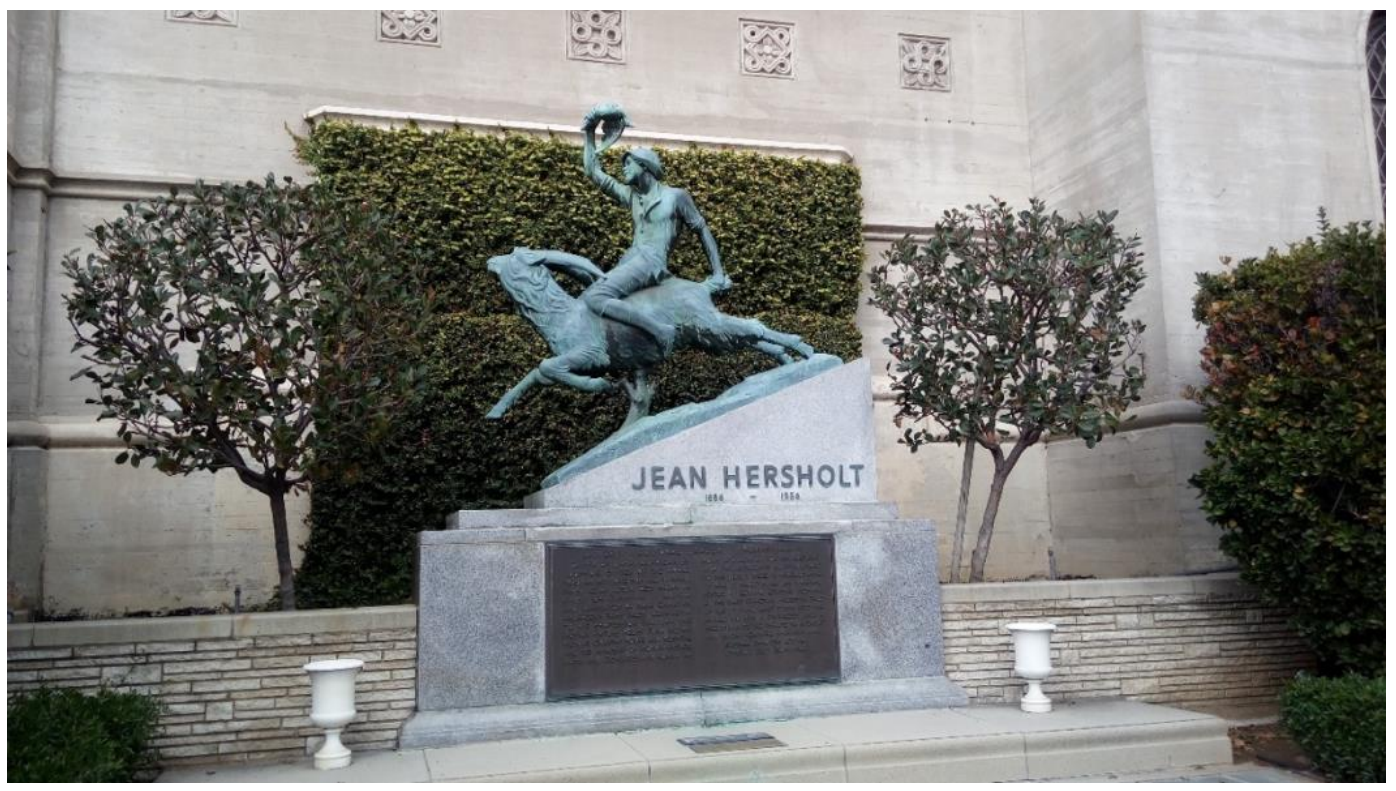

Figura 11: Cemitério Forest Lawn Memorial Park -Túmulo art déco. Fonte: Stela Barthel, 2017.

O cementerio de La Recoleta em Buenos Aires foi avaliado pela Revista Architectural Digest (revista fundada em 1920, referência em design de interiores e paisagismo) como um dos mais interessantes do mundo, principalmente pela arquitetura e é um dos destinos turísticos mais procurados da cidade. Está localizado no bairro de classe média e alta com o mesmo nome. 0 cemitério foi implantado nos jardins da basílica de Nossa Senhora do Pilar, que hoje é patrimônio nacional e é um parque.

Foi o primeiro cemitério público da cidade, mas hoje em dia acessível apenas à elite, pelo alto preço dos jazigos. Foi fundado em 1822, projetado pelo arquiteto e engenheiro francês Prosper Catelin, nos moldes do cemitério Père Lachaise, de Paris. O nome do bairro, Recoleta, deve-se aos monges da Ordem dos Recoletos. Por causa de uma epidemia de febre amarela, as famílias abastadas mudaram-se para a área Norte da cidade, onde depois o cemitério foi construído. Foram realizadas duas grandes reformas, uma em 1881, quando foi construído o edifício de entrada e a última em 2003 (Dejtiar, 2016).

Há muitas obras de arte e mausoléus considerados monumentos nacionais. Os variados estilos arquitetônicos vão desde o neoclássico do edifício de entrada, passando pelo ecletismo (Figura 12), com uma justaposição de estilos no mausoléu-capela com feições neoclássicas, com 
frontão triangular, entablamento, arco pleno, mas com interferência dos adornos do período eclético, pilar (e não coluna) com caneluras, capitel estilizado, sem ordem arquitetônica grecoromana, até o art déco, do início do século XX (Figura 13), identificado pelos planos superpostos e o escalonamento das platibandas e dos pórticos, além de frisos e relevos.

Outro mausoléu-capela art déco traz a imagem de um anjo (Figura 14). O túmulo mais visitado é o de Eva Perón (Figura 15), ex primeira-dama, esposa de Juan Domingo Perón, que se encontra no mausoléu da sua família (Duarte). Há elementos do estilo art déco, como frisos e planos escalonados.

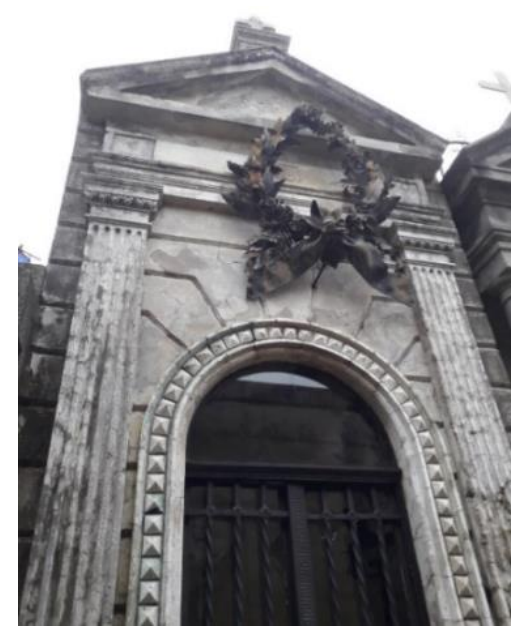

Figura 12: Cemitério de La Recoleta. MausoléuMausoléu- capela capela eclético. Fonte: Stela Barthel, 2019

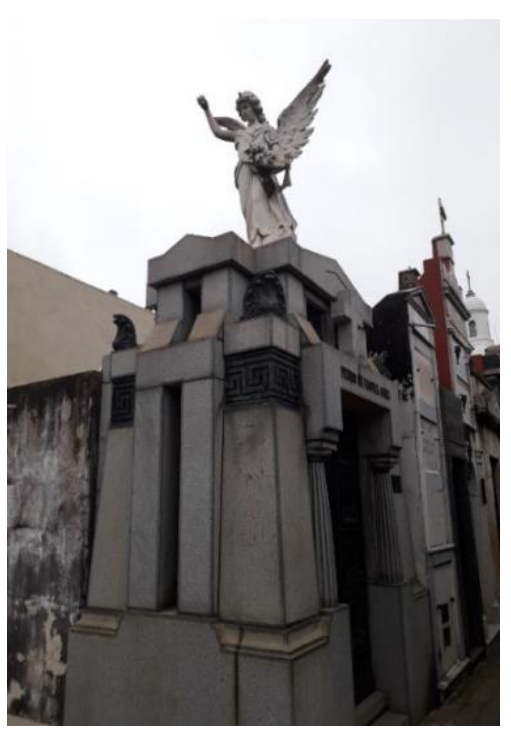

Figura 14: Cemitério de La Recoleta, Mausoléucapela art déco. Fonte: Stela Barthel, 2019.

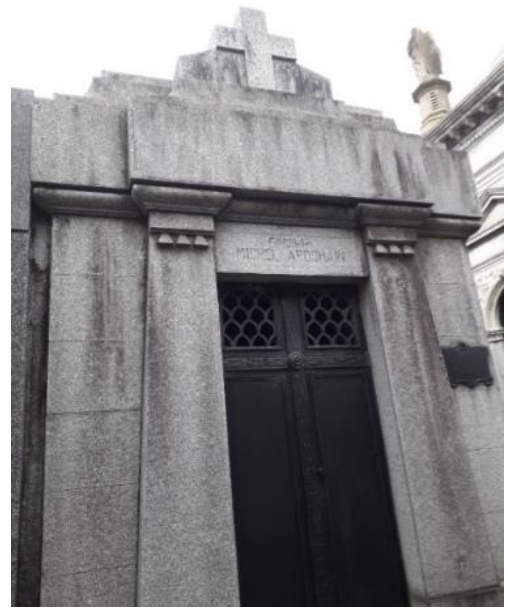

Figura 13: Cemitério de La Recoleta art déco. Fonte: Stela Barthel, 2019.

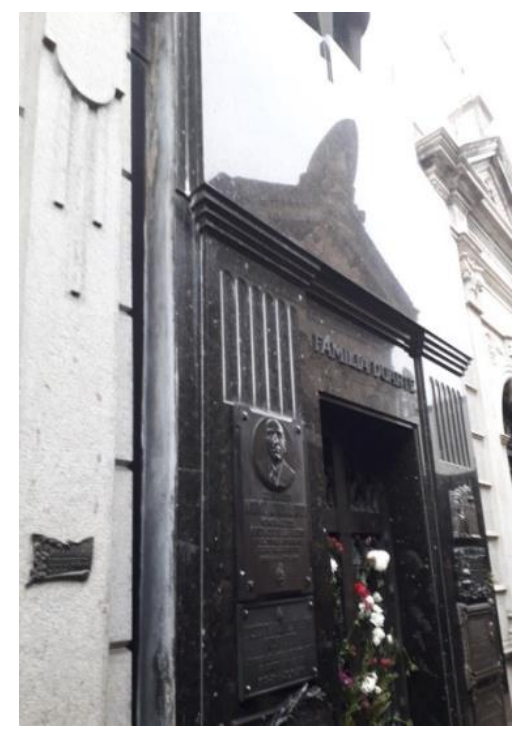

Figura 15: Cemitério de La Recoleta, Túmulo art déco. Eva Perón. Fonte: Stela Barthel, 2019 
Um mausoléu-capela eclético (neoegípcio, Figura 16) apresenta os pilones da arquitetura egípcia (pórtico com paredes inclinadas, lembrando as pirâmides), com relevos que aludem a elementos da arte egípcia, como o sol alado. Outro mausoléu-capela eclético (neobarroco, Figura 17), apresenta volutas no frontão e pilares (e não colunas) com alusão à ordem arquitetônica jônica.

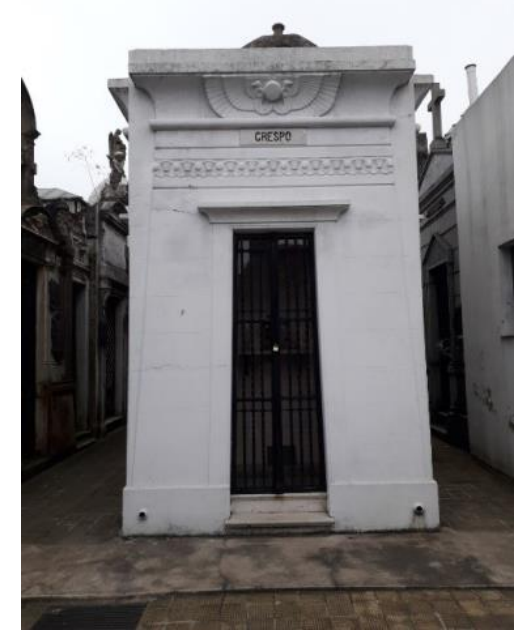

Figura 16: C. de La Recoleta Mausoléu-Capela eclético. Fonte: Stela Barthel, 2019.

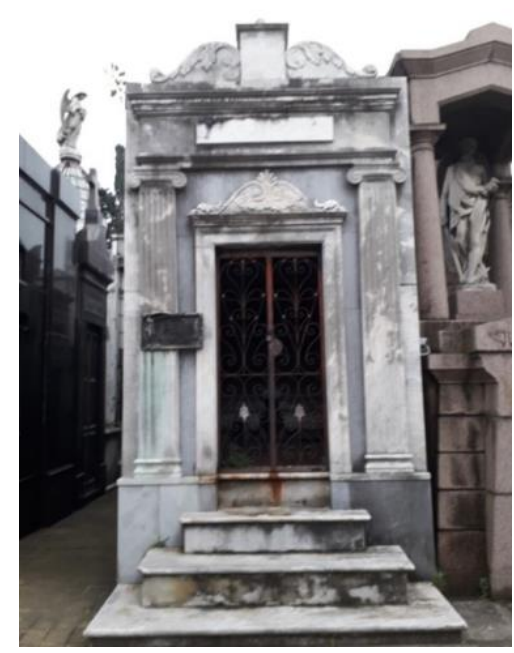

Figura 17: C. de La Recoleta, Mausoléu- capela eclético. Fonte: Stela Barthel, 2019.

O cemitério São João Batista, no Rio de Janeiro, localizado no bairro de Botafogo, é o único da zona Sul da cidade, tendo sido primeiramente administrado pela Santa Casa de Misericórdia. Segundo levantamento feito pela administração, a maioria dos enterramentos é católica. É um dos cemitérios mais importantes do país e destino turístico pelos edifícios, obras de arte e pelas personalidades enterradas ali, como chefes de estado, artistas, políticos, escritores, intelectuais. Foi o segundo cemitério público do Rio de Janeiro (Nogueira, 2013).

Foi inaugurado no dia 4 de dezembro de 1852, projetado pelo arquiteto Francisco Joaquim Béthencourt da Silva (Nogueira, 2011). O cemitério também abriga restos mortais provenientes de algumas igrejas e de outros cemitérios, como o da Praia da Saudade, que foi destruído por uma ressaca.

Os jazigos mais antigos têm a predominância do estilo neogótico (Figura 18), como o túmulo do Visconde e da Viscondessa de Itaborahy e eclético (Figura 19), como o do mausoléu-capela da família Guinle, antiga dona do Hotel Copacabana Palace. No primeiro, nota-se a verticalidade, os arcos ogivais e a torre alta e esguia, os coruchéus, no segundo, o uso de elementos da arquitetura clássica, como o frontão triangular e o entablamento, pilares (e não 
colunas) alusivos à ordem arquitetônica jônica, com caneluras no fuste, mas misturados a ornamentos e relevos do ecletismo.

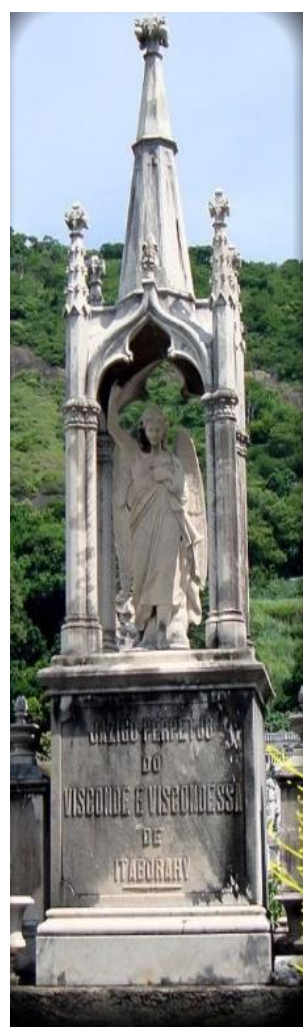

Figura 18: Cemitério São João Batista. Túmulo neogótico. Visconde de Itaborahy. Fonte: www.tumulosfamosos.blogger

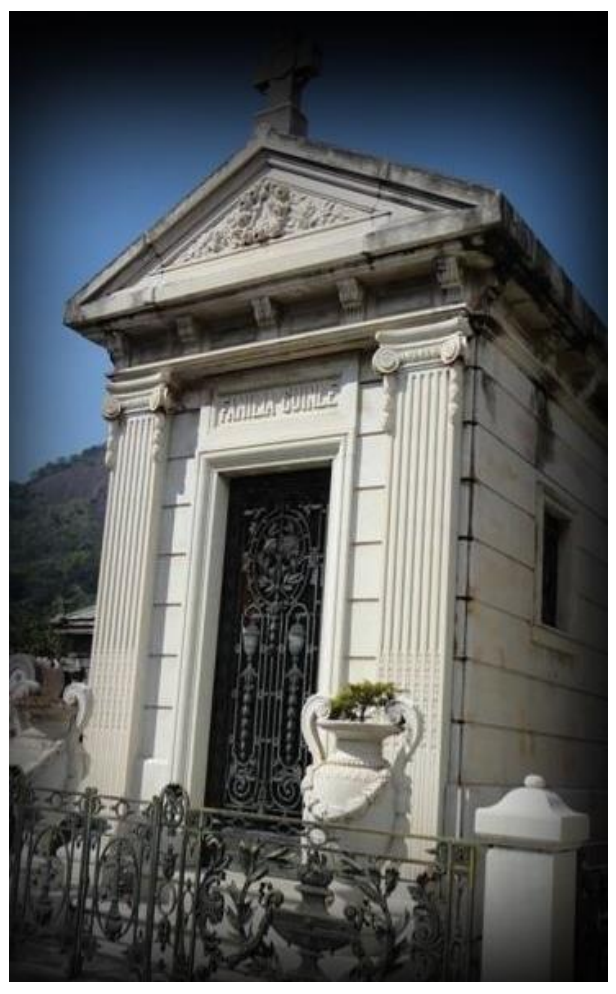

Figura 19: Cemitério São João Batista. Mausoléucapela eclético família Guinle. Fonte: www.tumulo-artistabrasileiro

O mausoléu-monumento da Academia Brasileira de Letras (Figura 20) foi construído em 1962 e é modernista, tem aberturas na fachada e aplicação de granito, formando uma espécie de mosaico e não tem ornamentos. A cobertura é uma casca de concreto que forma uma marquise na entrada. 


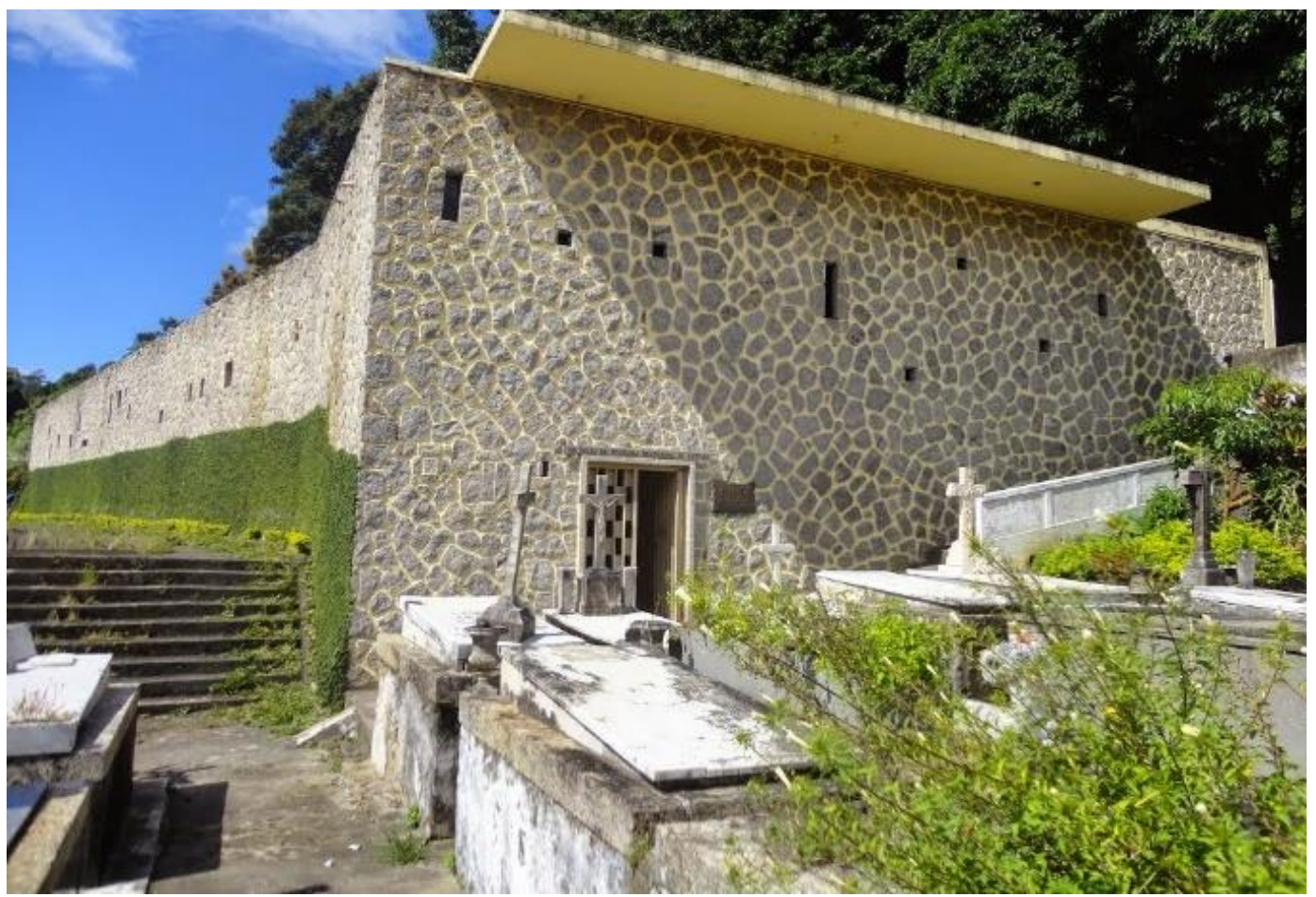

Figura 20: Cemitério São João Batista. Mausoléu-monumento modernista. Academia Brasileira de Letras. Fonte: www.pro.rio.rj.gov.br

O mausoléu-monumento da Marinha do Brasil- Divisão Naval em Operações de Guerra -DNOG (Figura 21), é art déco, tem planos superpostos e escalonamento. Teve projeto do escultor Hildegardo Leão Velloso, que elaborou as estátuas (Piovesan; Grassi, 2014). Homenageia os mortos da Primeira Guerra Mundial. Há outro mausoléu-monumento da Marinha do Brasil, que homenageia os mortos do encouraçado São Paulo em 1924, art déco (Figura 22). Um túmulo art déco, é o de Carmem Miranda (Figura 23), com escalonamento e planos superpostos, revestido de granito avermelhado.

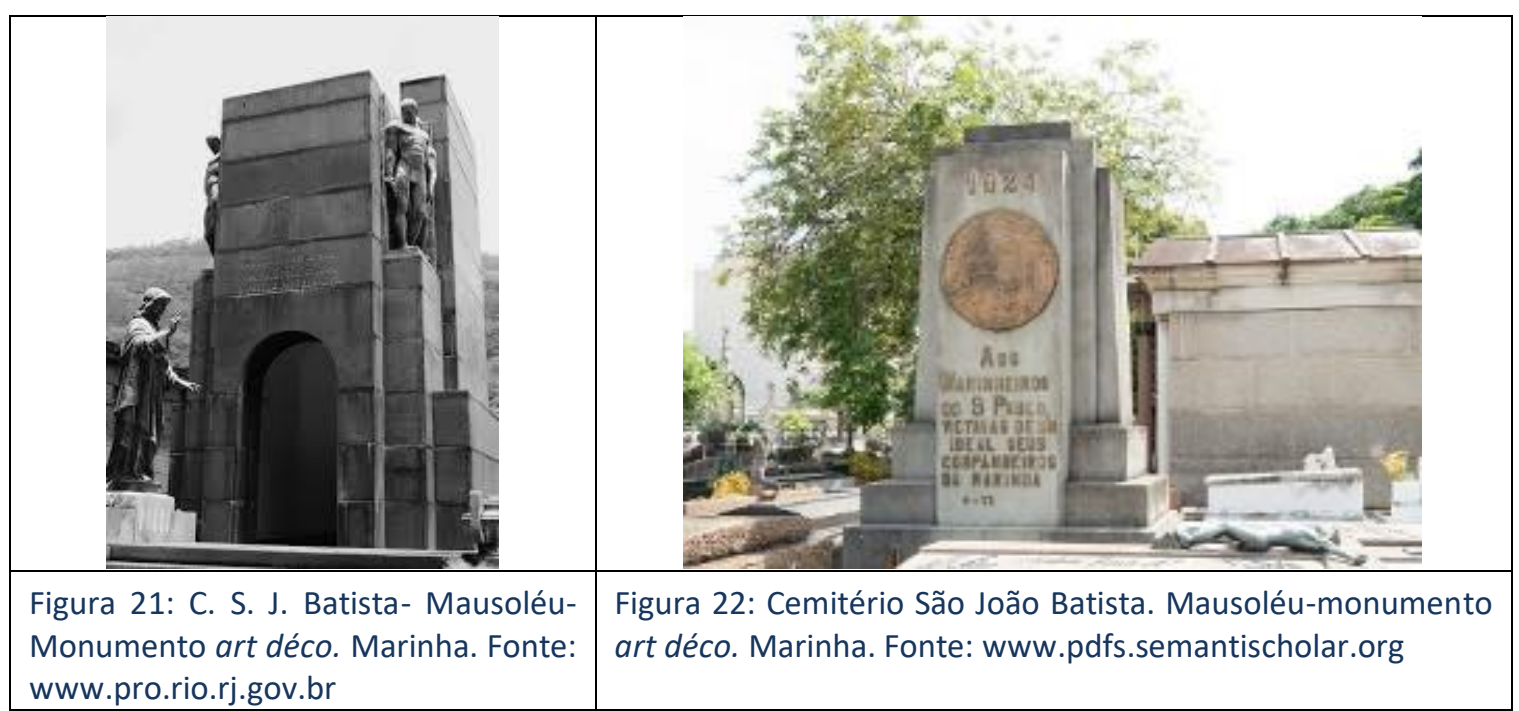




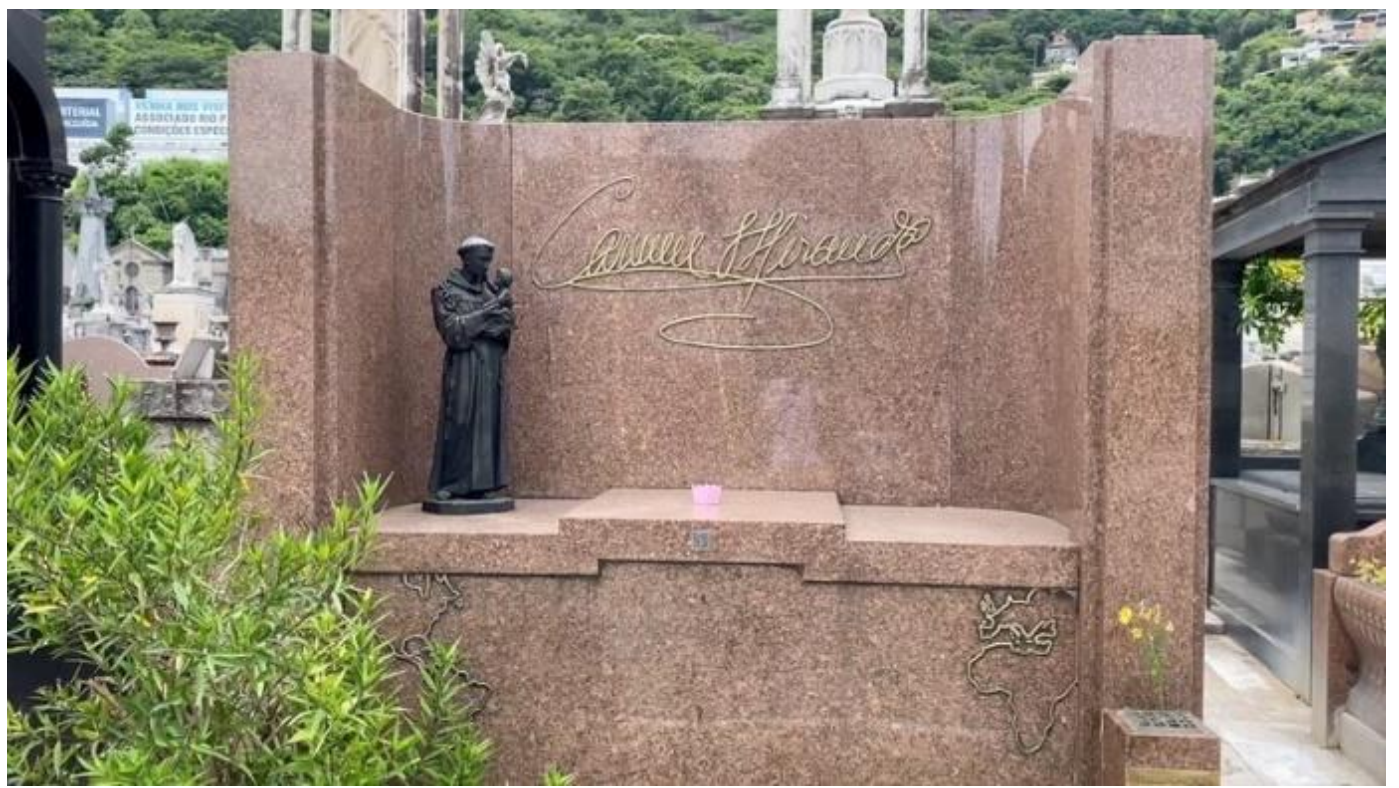

Figura 23: Cemitério São João Batista. Túmulo art déco. Carmem Miranda. Fonte: www.faellvas.com.br

$\mathrm{Na}$ cidade do Recife, o cemitério de Santo Amaro, que tem como nome oficial Senhor Bom Jesus da Redenção, é o mais antigo cemitério público. Hoje em dia o bairro de Santo Amaro faz parte da área central da cidade, porém no século XIX era um arrabalde. Sua localização estava em acordo com as posturas higienistas, o afastamento dos sepultamentos das áreas povoadas para evitar a proliferação de doenças. Foi inspirado nos cemitérios públicos europeus, sendo inaugurado em 1851, dez anos após a comissão chefiada pelo engenheiro francês Louis Lèger Vauthier, Diretor da Repartição de Obras Públicas, determinar a área para o empreendimento. O engenheiro ficou por seis anos em Pernambuco, sendo responsável por diversas obras importantes, como a construção do Teatro de Santa Isabel, tendo sido convidado pelo Conde da Boa Vista, Francisco do Rêgo Barros. Só foi possível iniciar a construção do cemitério em 1849, após uma epidemia de febre amarela. O engenheiro pernambucano José Mamede Alves Ferreira, que substituiu Vauthier quando este retornou a Paris, ficou responsável pela obra (Motta, 2009; Castro, 2007).

O portão de entrada é em ferro fundido, elemento da chamada "Arquitetura do ferro", produzido pela Fundição D'Aurora, que pertencia a um empresário inglês, Christopher Starr. A capela central do cemitério é neogótica e tem planta octogonal localizando-se na parte central do cemitério, no cruzamento das alamedas. Curiosamente, há jazigos quase idênticos em volta, apresentando verticalidade, arcos ogivais e coruchéus esguios e altos, como no mausoléu-capela (Figura 24) que copia a arquitetura da capela do cemitério. 


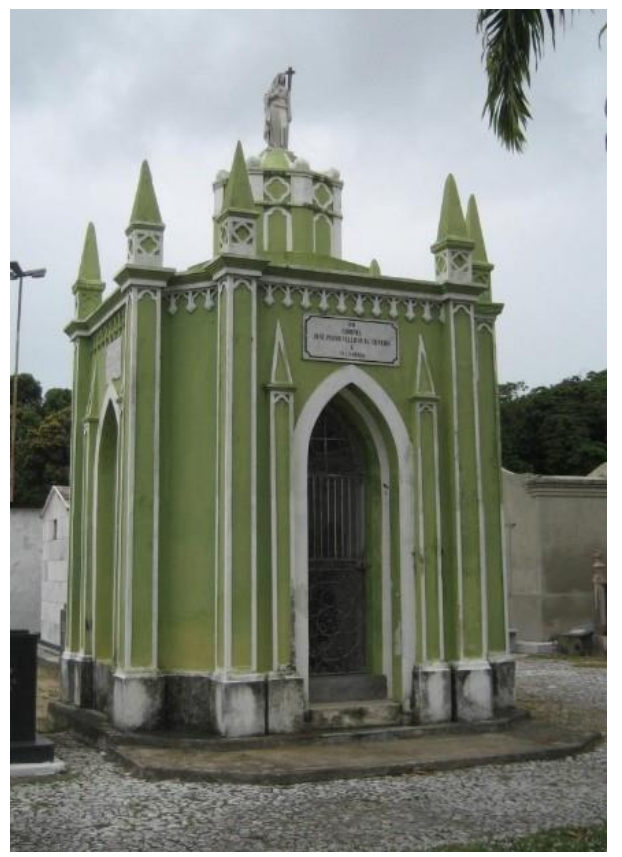

Figura 24: Cemitério de Santo Amaro. Mausoléu-capela neogótico. Fonte: Stela Barthel, 2018.

No Cemitério de Santo Amaro, há vários jazigos art déco, inclusive o mausoléu-monumento do ex-governador Agamenon Magalhães (Figura 25) e o mausoléu-monumento da Marinha do Brasil (Figura 26), hoje abandonado, ambos identificáveis pelos planos superpostos, pelo escalonamento, pelas imagens, e pela simetria.

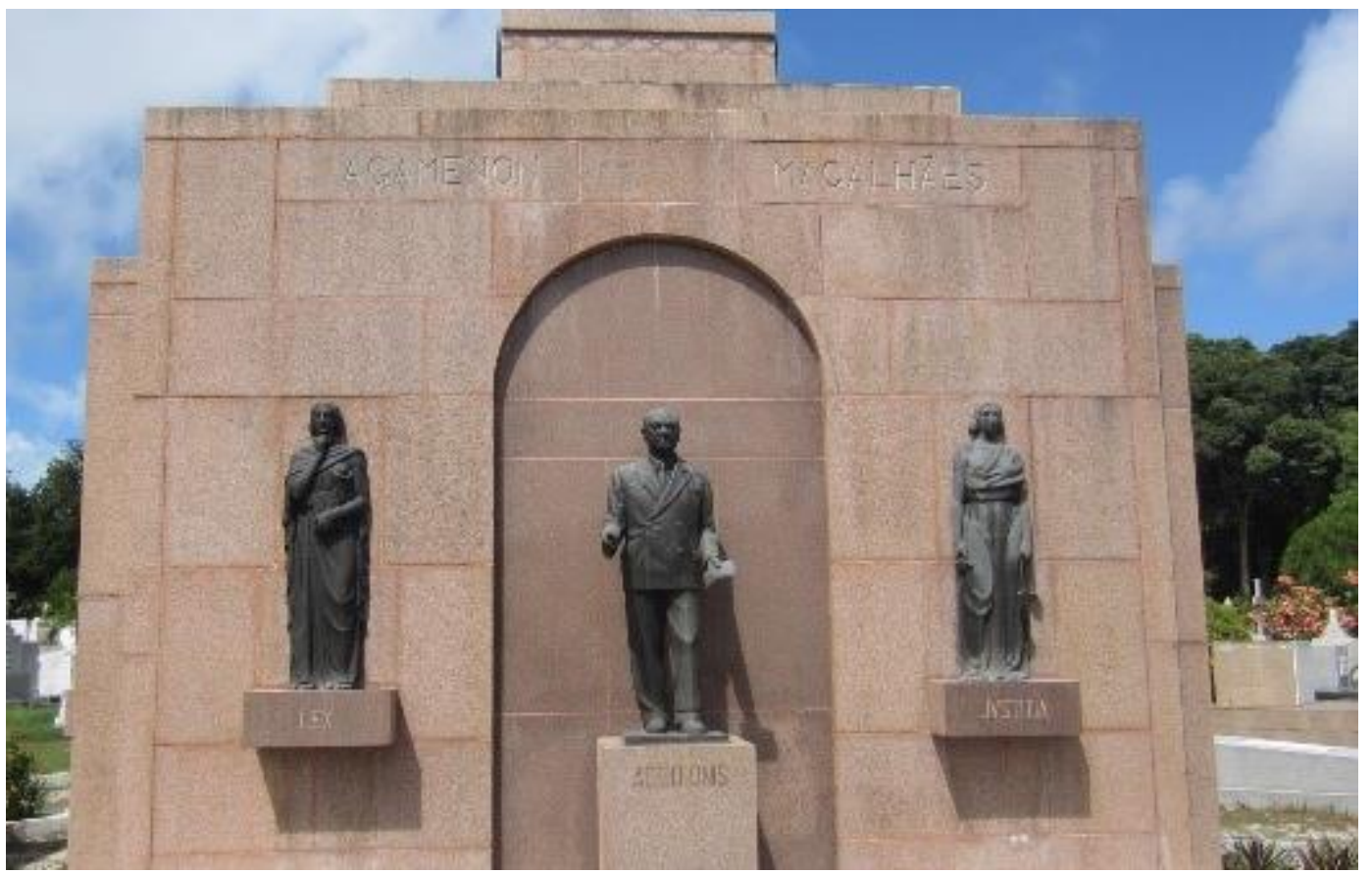

Figura 25: Cemitério de S. Amaro. Mausoléu-monumento art déco. Agamenon Magalhães. Fonte: Stela Barthel, 2014. 


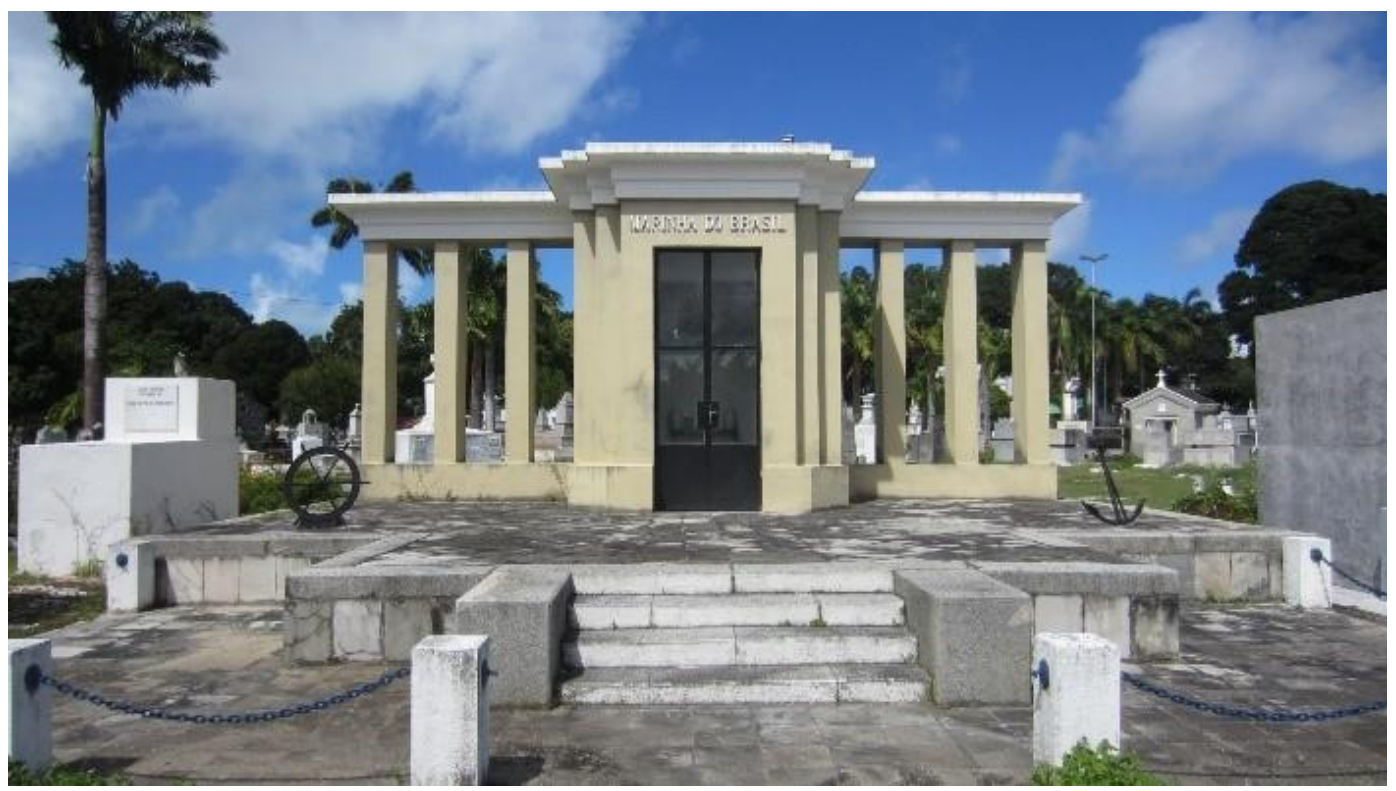

Figura 26: Cemitério de Santo Amaro. Mausoléu-monumento art déco. Marinha. Fonte: Stela Barthel, 2014.

Na categoria túmulos, há vários jazigos mais simples que também utilizam o estilo (Figuras 29 e 30), com escalonamento, planos superpostos, simetria.

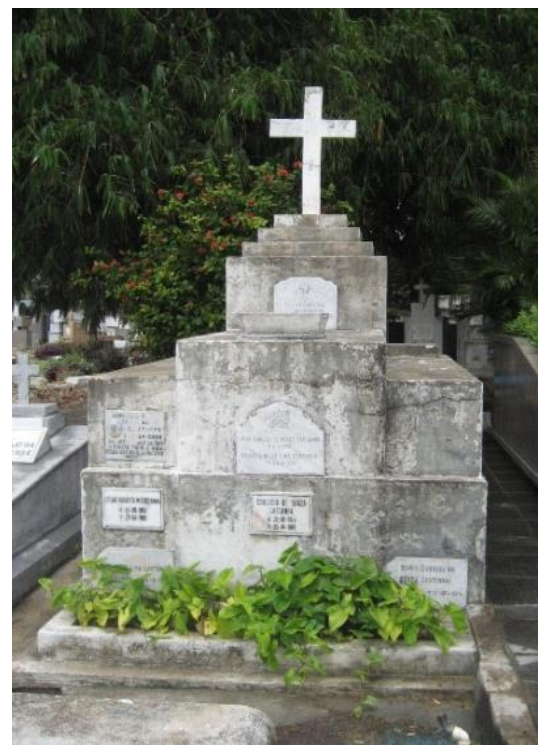

Figura 27: C. de S. Amaro. Túmulo art déco. Fonte: Stela Barthel, 2014.

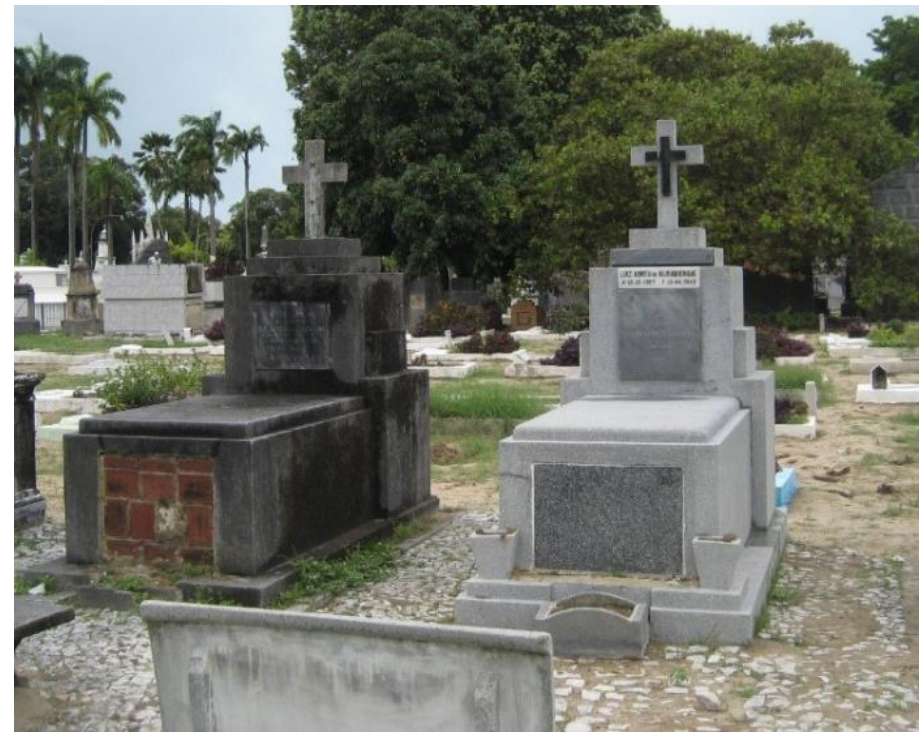

Figura 28: Cemitério de Santo Amaro. Túmulos art déco. Fonte: Stela Barthel, 2014.

Outro mausoléu-monumento art déco importante é o do Conselheiro Rosa e Silva, falecido em 1929 (Figura 29). Apresenta planos superpostos e escalonamento, imagens e é revestido de granito preto. 


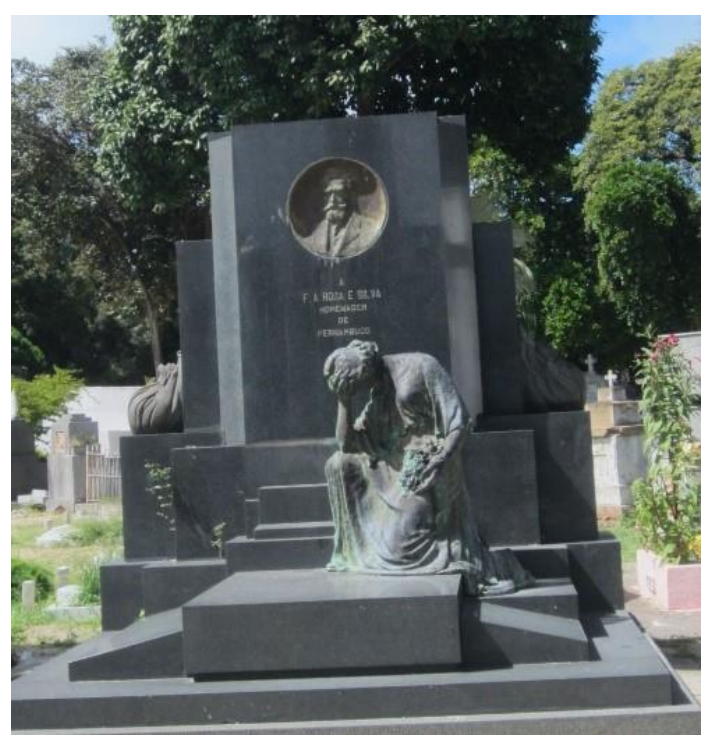

Figura 29: Cemitério de Santo Amaro. Mausoléumonumento art déco. Rosa e Silva. Fonte: Stela Barthel, 2018.

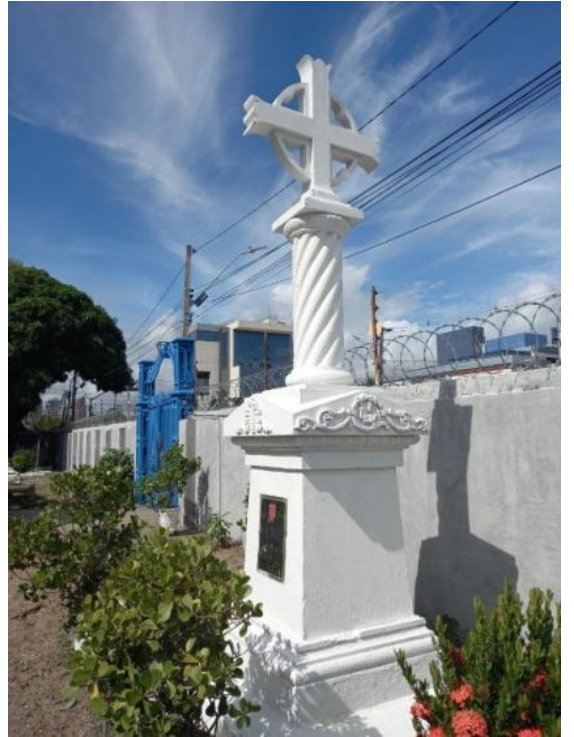

Figura 30: Cemitério dos Ingleses. Túmulo eclético. Abreu e Lima. Fonte: Stela Barthel, 2021.

Existem áreas nobres dentro do cemitério, onde se encontram os jazigos de personalidades importantes, grandes empresários e os mausoléus das famílias tradicionais.

Nesse mesmo bairro de Santo Amaro, foi fundado em 1814, o cemitério dos Ingleses com o nome de The British Cementery. Foi o primeiro cemitério extramuros do Recife.

A área onde hoje se localiza o cemitério dos Ingleses, no bairro de Santo Amaro, foi doada ao cônsul inglês no século XIX estando fora dos limites da cidade na época. Pertence hoje ao consulado britânico. A colônia inglesa era expressiva na cidade, estando envolvida em diversos empreendimentos, como bancos, correios, estradas de ferro, fábricas, exportação de açúcar e casas de câmbio (Melo, 2016). Por terem religião protestante, os ingleses ao morrer não podiam ser enterrados nas igrejas católicas, como era o costume do início do século XIX, sendo levados então para descampados e praias e enterrados ao lado de escravos, o que causava indignação.

O cemitério foi ampliado a partir de 1850, por causa do surto de febre amarela que ocorreu na cidade. Porém, nos finais dos anos de 1960, a avenida Cruz Cabugá, onde se localiza o cemitério, sofreu uma reforma e foi ampliada no governo de Augusto Lucena, causando uma perda expressiva de área na parte da frente, compensada com acréscimos laterais e nos fundos e alguns jazigos reposicionados (Beltrão, 2011). 
Entra-se por um portão de ferro fundido (componente da chamada "arquitetura do ferro" e em frente há uma capela com planta octogonal, com feições ecléticas. Há jazigos de várias pessoas de outras nacionalidades ali enterradas, não apenas ingleses e como curiosidade, o do general Abreu e Lima, desafeto do bispo Cardoso Aires, que proibiu seu enterro nas igrejas católicas da cidade, em 1869, por causa de polêmicas envolvendo a Maçonaria (Figura 30). 0 túmulo eclético apresenta uma base em forma de pirâmide truncada, com relevos, encimada por uma coluna salomônica (bastante usada no período do Barroco) e uma cruz.

A área do cemitério é pequena, mas apresenta diversos estilos e algumas curiosidades, como o túmulo em forma de pirâmide (Figura 31), eclético, neoegípcio. Há túmulos neoclássicos, como os exemplos a seguir, o primeiro com um pórtico onde se veem duas colunas da ordem toscana, um entablamento e um pódio (Figura 32) e o segundo com a representação de ruínas de um templo romano (Figura 33), apresentando um pódio e colunas da ordem arquitetônica toscana. Há ainda exemplares art déco (Figura 34), apresentando planos superpostos e escalonamento.

O cemitério dos ingleses foi tombado pela Fundação do Patrimônio Histórico e Artístico de Pernambuco (Fundarpe) em 1984.

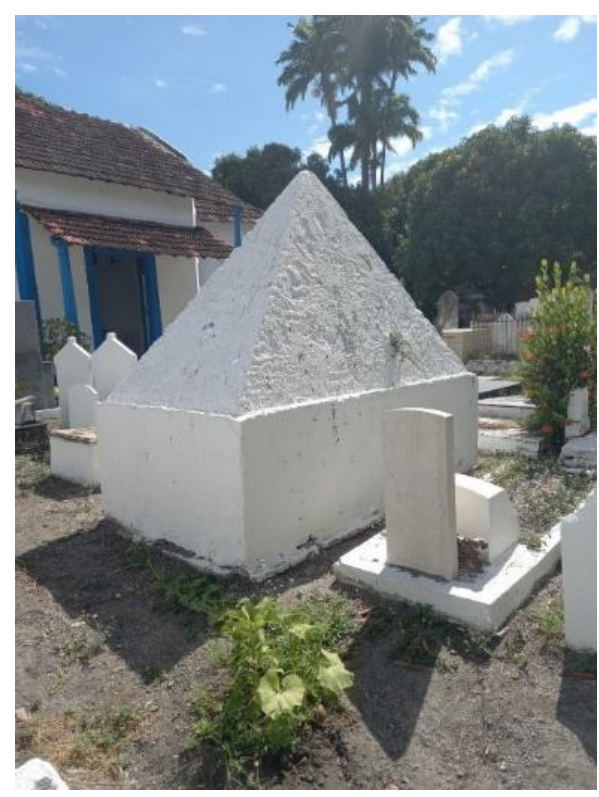

Figura 31: Cemitério dos Ingleses. Túmulo eclético. Fonte: Stela Barthel, 2021.

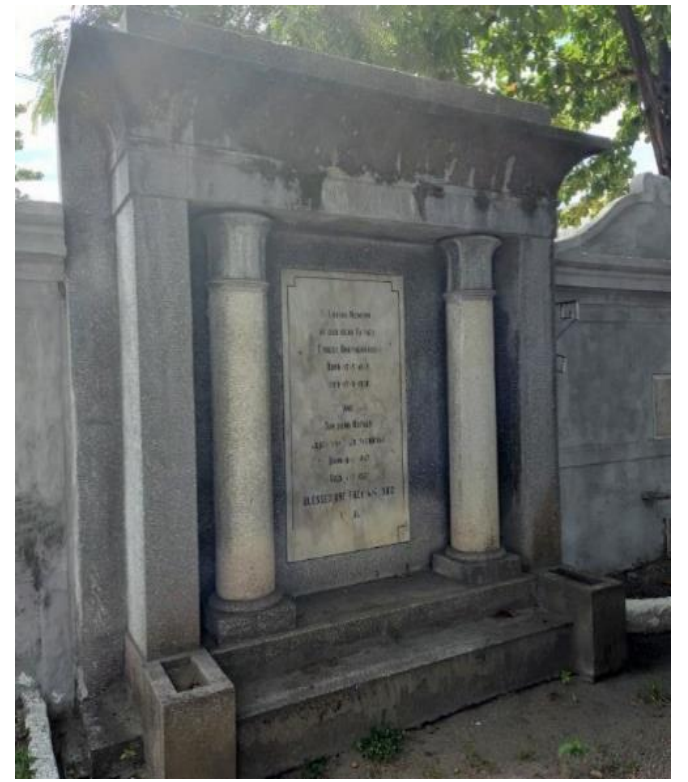

Figura 32: Cemitério dos Ingleses. Túmulo neoclássico. Fonte: Stela Barthel, 2021. 


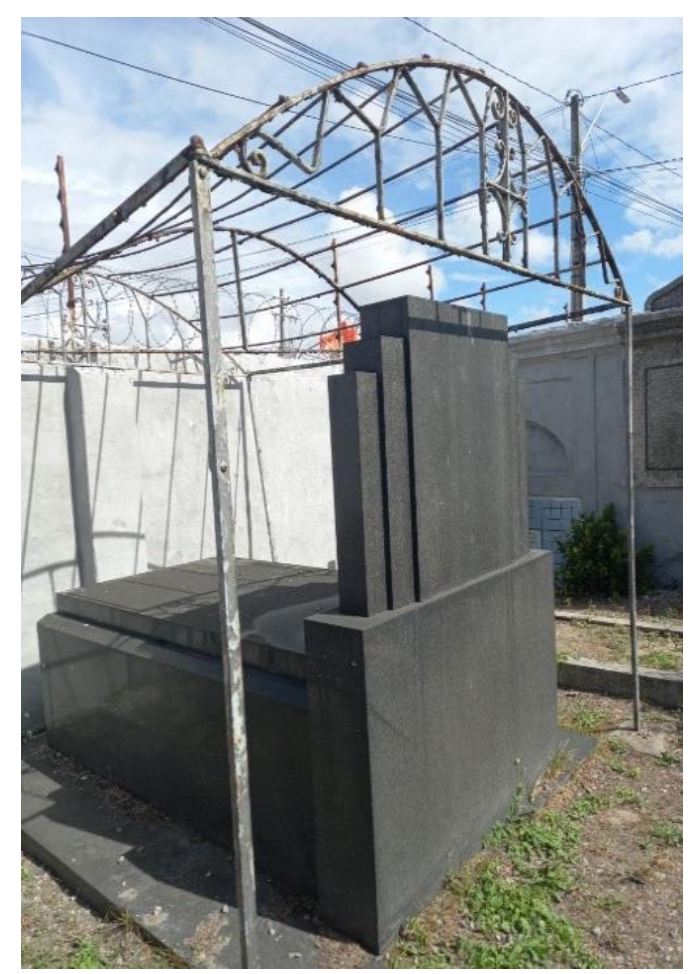

Figura 33: Cemitério dos Ingleses. Túmulo neoclássico. Fonte: Stela Barthel, 2021.

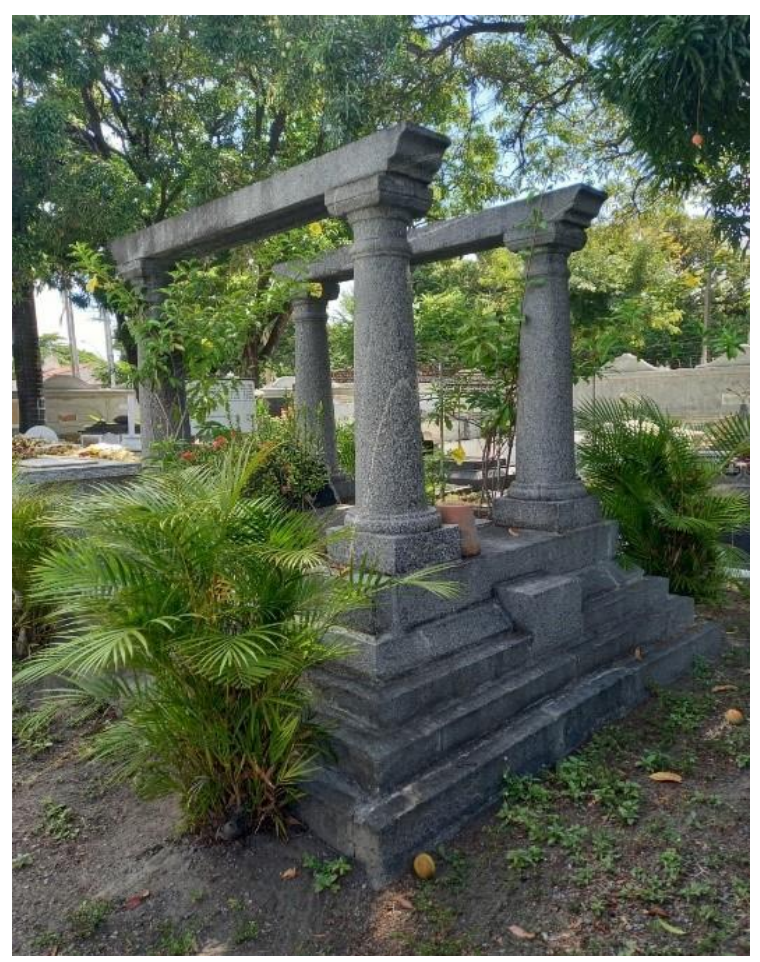

Figura 34: Cemitério dos Ingleses. Túmulo art déco. Fonte: Stela Barthel, 2021.

O cemitério de Casa Amarela tem como nome oficial Cemitério Bom Jesus do Arraial, em alusão ao forte luso-brasileiro Arraial Velho do Bom Jesus, que existiu ali entre 1630 e 1635 quando foi rendido pelas tropas da Companhia das Índias Ocidentais. Os vestígios desse forte estão localizados onde hoje existe um parque público municipal denominado Sitio da Trindade. O cemitério de Casa Amarela foi fundado em 1888, embora existam relatos que dão conta da existência de sepultamentos desde o início do século XIX, o que o configura como um dos cemitérios mais antigos da cidade, ao lado do cemitério dos Ingleses. Fica no largo de Casa Amarela, um dos bairros mais populosos do Recife, ao lado do mercado público e da feira.

Foi ampliado e tem também catacumbas e ossuários. Quando da construção do cemitério, o bairro de Casa Amarela era local de moradia de famílias de baixo poder aquisitivo e este cemitério tem como característica a não existência de jazigos suntuosos, como os do tipo mausoléu-capela e mausoléu-monumento, sendo a categoria túmulo a mais comum, ao lado das covas. Encontra-se neste momento em estado ruim de conservação. 
Os jazigos que apresentam estilo arquitetônico são simples, na maioria art déco (Figuras 35, 36, 37 e 38), com escalonamentos e planos superpostos nos túmulos.

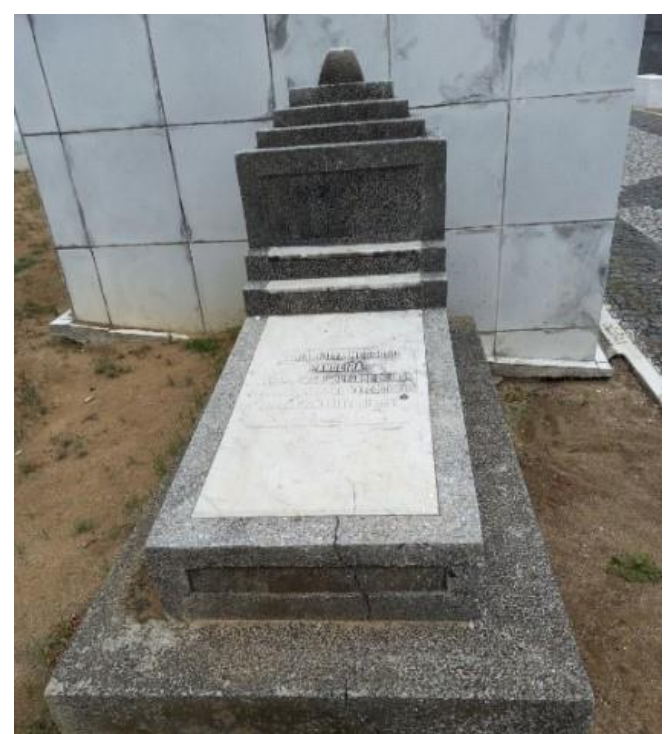

Figura 35: C. de Casa Amarela. Túmulo art déco. Fonte: Stela Barthel,2021

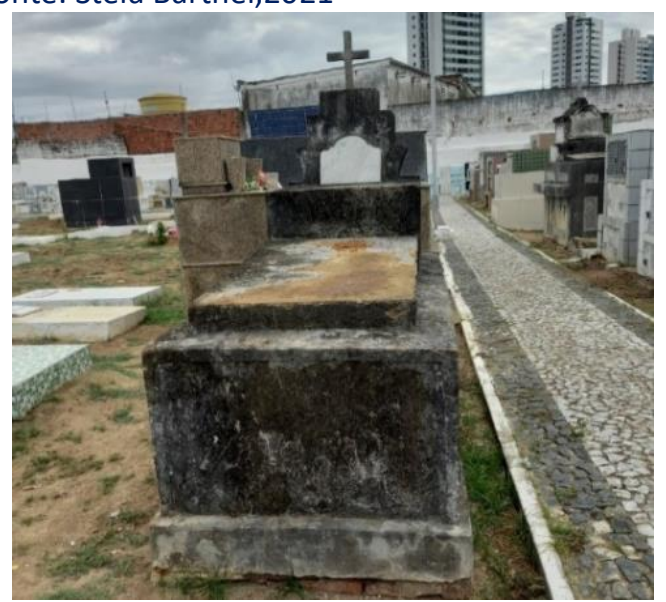

Figura 37: C. de Casa Amarela. Túmulo Art Déco. Fonte: Stela Barthel, 2021.

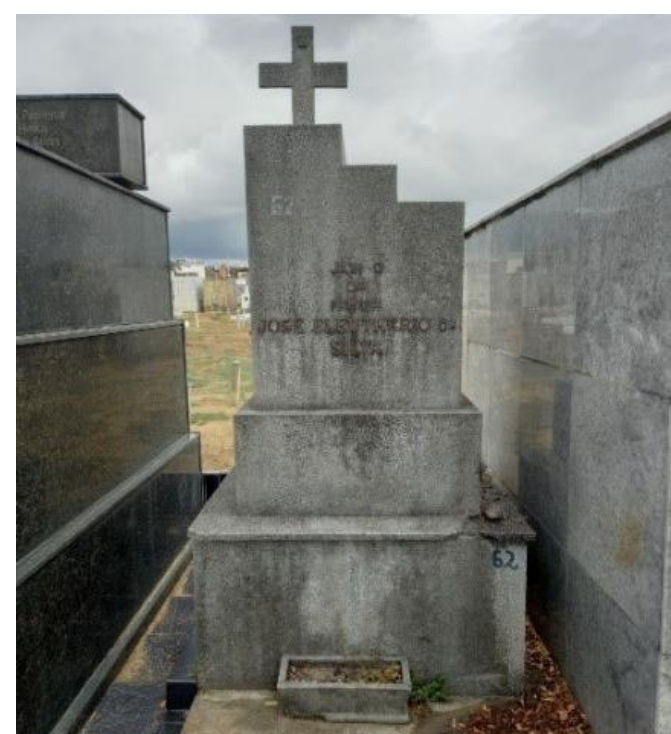

Figura 36: C. de Casa Amarela. Túmulo art déco. Fonte: Stela Barthel,2021.

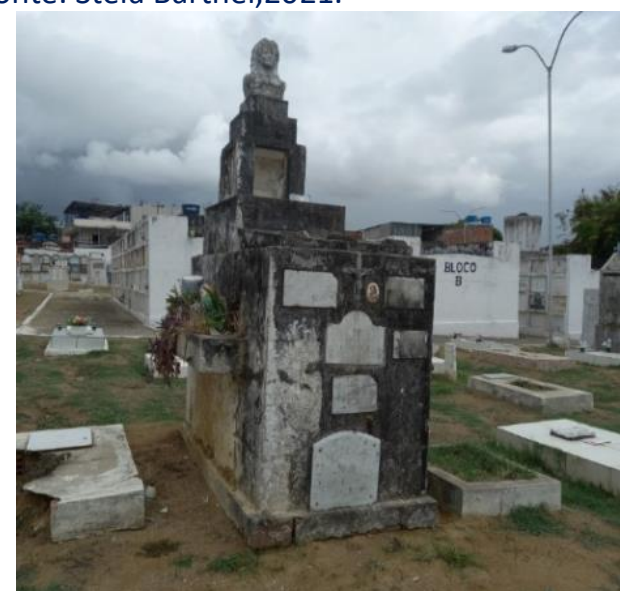

Figura 38: C. de Casa Amarela. Túmulo Art Déco. Fonte: Stela Barthel, 2021.

Assim como o cemitério de Santo Amaro, o cemitério de Casa Amarela está sendo objeto de pesquisas de professores e alunos do Programa Institucional de Bolsas de Iniciação Científica (PIBIC) e da Pós-graduação em Arqueologia da UFPE, dedicados aos estudos cemiteriais, além de outras instituições de pesquisa, pela grande importância que apresenta até hoje para os moradores daquele bairro.

\section{Considerações finais}


O estudo da arqueologia funerária tem se mostrado uma fonte de pesquisa com grande potencialidade de expansão. A riqueza do acervo existente nos cemitérios de Pernambuco está à disposição para ser pesquisada. Com o desenvolvimento dos estudos cemiteriais e o reconhecimento do valor desses espaços, objetiva-se, com a continuidade dos estudos, atuar na preservação dos mesmos, ampliando os inventários, registros gráficos, estilísticos, bibliográficos e fotográficos já realizados.

Cientes de que este tema compreende uma realidade bem mais complexa, envolvendo parâmetros e abordagens mais amplas e abrangentes, neste trabalho buscou-se apenas a materialidade que envolve a morte num pequeno universo de pesquisa. A variedade de construções e estilos presentes nos cemitérios pesquisados, associados aos valores históricos e culturais a eles agregados, mostram a importância museológica desses espaços, a despeito da localização ou do que foi investido em sua implantação. Neles ficaram evidentes que os estilos arquitetônicos identificados contam a história da sociedade e da forma como edificam os espaços destinados a seus mortos.

Nesse trabalho, especificamente, foram analisados 40 jazigos nos sete cemitérios estudados e apesar de não ser um número expressivo, pode-se vislumbrar um conjunto diversificado com os variados estilos desde quando os cemitérios extramuros foram criados, no século XIX, como o estilo neoclássico, até o modernismo do século XX. Neles foram ressaltados os estilos correspondentes às suas épocas com características, técnicas e materiais próprios.

Nos jazigos estudados, a maioria apresentou o estilo art déco, o que era de se esperar. Esse estilo, do início do século $X X$, foi adotado por todas as classes sociais em todo o mundo e simbolizava a modernidade e o progresso. Era fácil de ser copiado pelas classes menos favorecidas e não necessariamente precisava de um arquiteto para ser concebido (Barthel, 2015). O estilo eclético também foi utilizado expressivamente nos cemitérios estudados. Dentre os jazigos ecléticos analisados encontram-se o neocéltico, o neoegípcio, o neobarroco, e os neorromânicos, alguns deles só vistos em cemitérios fora do Brasil. O estilo neoclássico, 0 mais antigo, mostrou-se igualmente presente. O neogótico e o modernista, também são retratados nesse pequeno inventário inicial realizado.

Os jazigos com a tipologia mausoléu-capela e mausoléu-monumento também apresentam os diversos estilos dos respectivos momentos. Alguns são neoclássicos ou neogóticos, ou refletem o art déco, o ecletismo ou o modernismo. Nota-se que os maiores investimentos em termos de 
construção e de materiais empregados foram nos mausoléus-monumentos e nos mausoléuscapela, num indicativo de ostentação e pompa. Nos primeiros estão associadas obras de arte, como esculturas, relevos, painéis, letreiros. Nos segundos, ornamentos, relevos e letreiros. Os túmulos são a categoria onde se nota menos aparato e suntuosidade.

A arqueologia funerária configura-se um campo amplo e profícuo para os estudos cemiteriais. A pesquisa arqueológica nos cemitérios gera subsídios ao estudo da cultura material presente, que além da arquitetura e da arte, abarca a sua dinâmica espacial e paisagística.

\section{Referências}

ALMEIDA, M. G. 2007. Morte, cultura e memória - Múltiplas interseções: Uma interpretação acerca dos cemitérios oitocentistas situados nas cidades de Porto e Belo Horizonte. Doutorado em História. Faculdade de Filosofia e Ciências Humanas da Universidade Federal de Minas Gerais, Belo Horizonte.

ALMEIDA, M. G. 2013. Imagens e representações da morte. In: IV Encontro Nacional de Estudos da Imagem - I Encontro Internacional de Estudos da Imagem, Londrina, p. 1995-1975.

BARTHEL, S. G. A. 2015. Vestígios do Art Déco na cidade do Recife (1919-1961): abordagem arqueológica de um estilo arquitetônico. Tese de doutorado em Arqueologia. UFPE, Recife.

BELLOMO, H. R. 1988. A estatuária funerária em Porto Alegre (1900-1950). Dissertação de Mestrado em História. PUC-RS, Porto Alegre.

BELLOMO, H. R. (Org.). 2008. Cemitérios do Rio Grande do Sul. Arte. Sociedade. Ideologia. Edipucrs, Rio Grande do Sul.

BELTRÃO, R. 2011. Necrópole: a história de uma cidade silenciosa. Revista Continente, n. 131, p. 30-39.

BORGES, M. E. 1999. Arte Funerária: representação do vestuário da criança. Locus: Revista de História, v. 5, n. 2, p. 145-159. Disponível em: https://periodicos.ufjf.br/index.php/locus/article/view/20485. Acesso em: 25 jan. 2021.

BORGES, M. E. 2002. Arte funerária no Brasil, 1890-1930: oficio dos marmoristas italianos em Ribeirão Preto. Editora C/Arte, Belo Horizonte.

BORGES, M. E. 2016. Cemitério como museu a céu aberto. VII Congresso Internacional de imagens de morte: tempo e espaços de morte na sociedade. Disponível em: www.textofinal-cem.museuimagensdemorte.2016.pdf. Acesso em: 25 jan. 2021.

CASTRO, E. T. 2008. Aqui também jaz um patrimônio: identidade, memória e preservação patrimonial a partir do tombamento de um cemitério (o caso do Cemitério do Imigrante de Joinville/SC, 1962-2008). Dissertação de Mestrado em Urbanismo, História e Arquitetura da Cidade. UFSC / PGAU, Florianópolis.

CASTRO, E. T. 2010. Cemitérios em destaque: iniciativas nacionais e internacionais pela preservação do patrimônio funerário. Anais do III Encontro Nacional da ABEC. Piracicaba, p. 243-252.

CASTRO, E. T. 2013. Para cada morto, a sua cova: algumas restrições para o sepultamento de protestantes no Brasil, século XIX. Revista Inter-Legere, p. 157-172. 
CASTRO, V. V. 2007. Das igrejas ao cemitério: políticas públicas sobre a morte no Recife do século XIX. Fundação da Cultura Cidade do Recife, Recife.

COMERLATO, F. 2012. O Patrimônio Cemiterial do Município de Cachoeira, Recôncavo da Bahia. Revista Habitus, v. 10, n. 2, PUC Goiás, p.203-214.

COMERLATO, F.; SANTOS, R. R. DOS; BULCÃO, M. C.; GOMES, A. DE S. 2013. Preservação dos cemitérios de Cachoeira e São Félix, Bahia: apontamentos para a sua conservação. Revista Inter-Legere, v. 1, n. 12, p. 77-98.

COSTA, G. S.; CASTRO, V. M. C. 2015. Patrimônio funerário do Cemitério Histórico de Santo Amaro, no Recife: estado de conservação dos primeiros túmulos. Fumdhamentos, v. XII, p. 50-73.

CYMBALISTA, R. 2002. Cidade dos vivos: arquitetura e atitudes perante a morte nos cemitérios do estado de São Paulo. FAPESP/Annablume. São Paulo.

CRUZ, L. R. N. S. 2019. Arqueologia no cemitério dos ingleses, em Santo Amaro, Recife - PE: uma análise da arte tumular durante o século XIX e primeira metade do século XX. Trabalho de Conclusão de Curso, Bacharelado em Arqueologia, Universidade Federal de Pernambuco, Recife.

DANSEL, M 1976. Au Père Lachaise: son histoire, ses secrets, ses promenades. Fayard, Paris.

DEL BRENNA, G. R. 1987. O neogótico romântico do período Imperial. In: FABRIS, Annateresa (Org.). Ecletismo na Arquitetura Brasileira. Nobel/EDUSP. São Paulo, p. 41-52.

DEJTIAR, F. 2016. Cementerio La Recoleta: história de uno de los cementerios más increíbles del mundo. ArchDaily Brasil. Disponível em: https://www.archdaily.com.br/br/802490/a-historia-do-cemiteriola-recoleta-um-dos-mais-incriveis-do-mundo. Acesso em: 9 jan. 2021.

FAVARETTO, B. 2017. Enquadramento histórico dos cemitérios. Disponível em: <https://brunafavaretto.jusbrasil.com.br/artigos/426293340/enquadramento-historico-doscemiterios>. Acesso em: 11 de jan. 2021.

FREITAS, P. C.; RAMOS, A. C. P. T.; KAUFMAN, T. N. 2019. Tem judeu aí? Arqueologia das práticas funerárias do Sitio Pilar, Recife-PE. Fumdhamentos, v. XVI, n.2, p. 73-103.

FUCHS, F. 2019. Espaços de cemitério e a cidade de São Paulo. Dissertação de Mestrado em Arquitetura. FAUUSP, São Paulo.

GOMBRICH, Ernst Hans 1999. A História da Arte. LTC, Rio de Janeiro.

GOMES, G. 1987. Arquitetura eclética em Pernambuco. In: FABRIS, A. (Org.). Ecletismo na Arquitetura Brasileira. Nobel/EDUSP. São Paulo, p. 176-207.

GOMES, A. 2013. O processo de secularização do Brasil no limiar da Republica e a criminalização do espiritismo. Sacrilegens, v.10, n. 1, p. 83-93.

GRAEFF, E. 1979. Edifício. Cadernos Brasileiros de Arquitetura. Editora Projeto, São Paulo.

Great Mausoleum Tour Guide (s/d). Forest Lawn Museum. Los Angeles.

GOITIA, F. C. 1995. História Geral da Arte. Editora del Prado. Madrid.

KOCH, W. 1982. Estilos de Arquitetura: a Arquitetura europeia da Antiguidade aos nossos dias. Editorial Proença, Lisboa.

KOCH, W. 2001. Dicionário dos estilos arquitetônicos. Martins Fontes, São Paulo. 
LEMOS, C. 1987. Ecletismo em São Paulo. In: FABRIS, Annateresa (Org.). Ecletismo na Arquitetura Brasileira. Nobel/EDUSP. São Paulo, p. 68-99.

LIMA, T. A. 1994. De morcegos e caveiras a cruzes e livros: a representação da morte nos cemitérios cariocas do século XIX (estudo de identidade e mobilidade sociais). Anais do Museu Paulista, São Paulo, v. 2 , p. $87-150$.

MACHADO, F. D. C.; CASTRO, V. M. C. 2017. Arqueologia funerária no Cemitério de Santo Amaro, RecifePE: jazigos e signos da elite recifense na segunda metade do século XIX. Clio Arqueológica, v. 32, n. 2, p.187-208.

MEDEIROS, J. C. 2012. Germinal: Morte e Sepultamento de Pretos Novos no Rio de Janeiro do Século XIX. Habitus, v. 10, n. 2, p. 173-185.

MELO, J. C. 2016. A primeira ferrovia inglesa no Brasil: The Recife- São Francisco Railways. CEPE, Recife.

MOTTA, A. 2009. À flor da pedra: formas tumulares e processos sociais nos cemitérios brasileiros. Fundação Joaquim Nabuco, Recife.

NOGUEIRA, R. S. 2011. Descobrindo o Art Déco no Cemitério São João Batista. 9o. Seminário DOCOMOMO Brasil- Interdisciplinaridade e experiências em documentação e preservação do patrimônio recente, p 1-14.

NOGUEIRA, R. S. 2013. Quando um cemitério é patrimônio cultural. Dissertação de mestrado em Memória Social, Universidade Federal do Estado do Rio de Janeiro, Rio de Janeiro.

ORSER, C. E. Jr. 1992. Introdução à Arqueologia Histórica. Editora Oficina de Livro, Belo Horizonte.

PAZ, R. A. 2018. A arte tumular do cemitério de Santo Amaro, no Recife: Uma análise das representações das imagens femininas.. Trabalho de Conclusão de Curso (Bacharelado em Arqueologia) - Universidade Federal de Pernambuco, Recife.

PEARSON, M. P. 1982. Mortuary practices, society and ideology: na ethnoarchaeological study. In: HODDER, Ian. Simbolic and structural Archaeology. Cambridge University Press. Cambrige/Paris, p. 99113.

PIOVESAN, A.; GRASSI, C. 2014. Morte e guerra: o mausoléu dos mortos do Brasil na Primeira Guerra Mundial - Cemitério São João Batista (1928). Revista AGCRJ, n. 8, p. 219-236.

REIS, J. J. 1997. O cotidiano da morte no Brasil Oitocentista. In: ALENCASTRO, L. F. História da vida privada no Brasil. Companhia das Letras, São Paulo, p. 95-141.

REIS, J. J. 2011. Quem manda em Salvador?: governo local e conflito social na greve de 1857 e no protesto de 1858 na Bahia. In: DANTAS, M. D. (Org.). Revoltas, motins, revoluções: homens livres e libertos no Brasil do século XIX. Alameda. São Paulo, p. 431-448.

RODRIGUES, C. 1997. Lugares dos mortos na cidade dos vivos: tradições e transformações fúnebres no Rio de Janeiro. Secretaria Municipal de Cultura, Rio de Janeiro.

RODRIGUES, C. 2005. Nas fronteiras do Além: a secularização da morte no Rio de Janeiro (séculos XVIII e XIX). Rio de Janeiro: Arquivo Nacional, 2005.

RODRIGUES, C. 2014. A criação dos cemitérios públicos do Rio de Janeiro enquanto "campos santos" (1798-1851). Revista ACHRJ, n. 8, p. 257-278. 
SANTOS. E. V. A. 2016. Arqueologia no cemitério de Santo Amaro: Uma análise decorativa dos túmulos históricos. Trabalho de Conclusão de Curso, Bacharelado em Arqueologia, Universidade Federal de Pernambuco, Recife.

SILVA, R. A. P. 2019. Arqueologia funerária e representações sociais de gênero no cemitério histórico de Santo Amaro (Recife 1851-1930). Mestrado em Arqueologia, Universidade Federal de Pernambuco, Recife.

SOUSA, A. J. 2000. O classicismo arquitetônico no Recife Imperial. Editora Universitária UFPB/Fund. João Fernandes da Cunha, João Pessoa/Salvador.

VALLADARES, C. P.1972. Arte e sociedade nos cemitérios brasileiros: um estudo da arte cemiterial ocorrida no Brasil desde as sepulturas de igrejas e as catacumbas de Ordens e Confrarias até as necrópoles secularizadas (2 v.) Conselho Federal de Cultura, Rio de Janeiro. 